\title{
Enrichment in ${ }^{13} \mathrm{C}$ of atmospheric $\mathrm{CH}_{4}$ during the Younger Dryas termination
}

\author{
J. R. Melton ${ }^{1, *}$, H. Schaefer ${ }^{2}$, and M. J. Whiticar ${ }^{1}$ \\ ${ }^{1}$ School of Earth and Ocean Sciences, University of Victoria, P.O. Box 3065 STN CSC, Victoria, BC V8W 3V6, Canada \\ ${ }^{2}$ National Institute of Water and Atmospheric Research Ltd., 301 Evans Bay Pde, Wellington, 6021, New Zealand \\ *now at: Canadian Centre for Climate Modelling and Analysis, Environment Canada, Victoria, BC, V8W 2Y2, Canada
}

Correspondence to: J. R. Melton (joe.melton.sci@gmail.com)

Received: 13 September 2011 - Published in Clim. Past Discuss.: 12 October 2011

Revised: 13 June 2012 - Accepted: 21 June 2012 - Published: 19 July 2012

\begin{abstract}
The abrupt warming across the Younger Dryas termination ( $\sim 11600$ yr before present) was marked by a large increase in the global atmospheric methane mixing ratio. The debate over sources responsible for the rise in methane centers on the roles of global wetlands, marine gas hydrates, and thermokarst lakes. We present a new, higher-precision methane stable carbon isotope ratio $\left(\delta^{13} \mathrm{CH}_{4}\right)$ dataset from ice sampled at Påkitsoq, Greenland that shows distinct ${ }^{13} \mathrm{C}$ enrichment associated with this rise. We investigate the validity of this finding in face of known anomalous methane concentrations that occur at Påkitsoq. Comparison with previously published datasets to determine the robustness of our results indicates a similar trend in ice from both an Antarctic ice core and previously published Påkitsoq data measured using four different extraction and analytical techniques. The $\delta^{13} \mathrm{CH}_{4}$ trend suggests that ${ }^{13} \mathrm{C}$-enriched $\mathrm{CH}_{4}$ sources played an important role in the concentration increase. In a first attempt at quantifying the various contributions from our data, we apply a methane triple mass balance of stable carbon and hydrogen isotope ratios and radiocarbon. The mass balance results suggest biomass burning (42-66\% of total methane flux increase) and thermokarst lakes (27-59\%) as the dominant contributing sources. Given the high uncertainty and low temporal resolution of the ${ }^{14} \mathrm{CH}_{4}$ dataset used in the triple mass balance, we also performed a mass balance test using just $\delta^{13} \mathrm{C}$ and $\delta \mathrm{D}$. These results further support biomass burning as a dominant source, but do not allow distinguishing of thermokarst lake contributions from boreal wetlands, aerobic plant methane, or termites. Our results in both mass balance
\end{abstract}

tests do not suggest as large a role for tropical wetlands or marine gas hydrates as commonly proposed.

\section{Introduction}

Ice core records from both Antarctica and Greenland demonstrate numerous abrupt climate changes throughout the Quaternary (Brook et al., 2000). One such event, the Younger Dryas-Preboreal transition (YD-PB) $[\sim 1.6$ kiloyears before $1950 \mathrm{AD} ; \mathrm{ka} . \mathrm{BP}$, saw a rapid climate change leading a large increase in the atmospheric methane mixing ratio $\left(\left[\mathrm{CH}_{4}\right]\right)$ (Severinghaus et al., 1998). This increase could have been driven by changes in either the methane sources or sinks. However, modelling studies investigating interglacial-glacial changes in the predominant $\mathrm{CH}_{4}$ tropospheric sink, the $\mathrm{OH}$ radical, indicate only a small variability in sink strength (Thompson et al., 1993; Martinerie et al., 1995). Interpretation of the YD-PB CH 4 record has thus focused on methane's natural sources with the debate centering on the roles of tropical wetlands (Chappellaz et al., 1990; Brook et al., 2000), marine gas hydrates (Kennett et al., 2003), and thermokarst lakes (Walter et al., 2007).

Wetlands are the most important natural methane source, accounting for approximately $75 \%$ of global emissions in the Preindustrial Holocene (PIH) (Chappellaz et al., 1993; Wuebbles and Hayhoe, 2002); thus, the wetland hypothesis purports that an invigorated hydrologic cycle with higher precipitation allows expansion of wetland area, and 
increased wetland methane emissions, particularly in the tropics (Brook et al., 1996).

The clathrate (methane hydrate) release hypothesis comprises several scenarios. One contends that marine clathrates situated on the continental margins are capable of episodic destabilization events triggered by the warming of the upper thermocline waters. This scenario assumes that the majority of released methane passes through the water column, without oxidation, to the atmosphere (Kennett et al., 2003). A recent update on this hypothesis, based upon preserved tar records in sediments from the Santa Barbara basin, proposes that methane hydrates may act as a "climate sensitive valve system for thermogenic hydrocarbons", i.e. clathrate release allows for the increased release of methane from hydrocarbon seeps (Hill et al., 2006).

Thermokarst lakes have been shown to release very large amounts of methane from point-source locations with hotspots that produce up to $50 \mathrm{~g} \mathrm{CH}_{4} \mathrm{~m}^{2} \mathrm{yr}^{-1}$ (Walter et al., 2006). The large amount of available carbon (Zimov et al., 2006) and the high methane emission potential make thermokarst lakes a potential player in past abrupt climate changes (Walter et al., 2007).

The stable and radiogenic isotope ratios $\left({ }^{13} \mathrm{C} /{ }^{12} \mathrm{C}, \mathrm{D} / \mathrm{H}\right.$, ${ }^{14} \mathrm{C} /{ }^{12} \mathrm{C}$ ) of atmospheric methane trapped in glacial ice can be used to probe the dynamics of methane's sources and sinks (Schaefer et al., 2006; Sowers, 2006; Fischer et al., 2008; Petrenko et al., 2009) and distinguish between these competing hypotheses. Primary methane sources have characteristic isotope signatures, although in some cases with similar and/or broadly ranging values for a single isotope system (Whiticar, 1999). However, the combination of all three methane isotopes overcomes many of their individual limitations, and is used here to investigate the dynamics behind the $\mathrm{CH}_{4}$ flux increase during the YD-PB.

\section{Methods}

\subsection{Sample collection and analysis}

Ice samples were collected using un-lubricated chainsaws from the western margin of the Greenland ice sheet at Påkitsoq $\left(69^{\circ} 825.830 \mathrm{~N}, 50^{\circ} 815.200 \mathrm{~W}\right)$ during the $2003-$ 2005 sampling seasons. The start and end points of the Younger Dryas-Preboreal transition (YD-PB) in a sampling profile were determined in the field using gas chromatography with a flame ionization detector (GC-FID) analysis of $\left[\mathrm{CH}_{4}\right]$. This was later confirmed on parallel samples (collected along strike of the layers) by GC-FID $\left[\mathrm{CH}_{4}\right]$ analysis at Oregon State University (OSU), USA and $\delta^{15} \mathrm{~N}$ and $\delta^{18} \mathrm{O}_{\text {atm }}$ analysis at Scripps Institution of Oceanography, USA (Petrenko et al., 2006). The strike and dip of the ice was determined by visual cues as well as laboratory analysis (Petrenko et al., 2006). Ice from the actual YD-PB transition period is confined to $50 \mathrm{~cm}$ width and is directly accessible at the surface for precision sampling. Sample width was between 3 and $5 \mathrm{~cm}$ perpendicular to the strike of the profile. The YD-PB transition was resolved in great detail with ca. 6 to 8 age horizons, and 1 to 5 replicates sampled at each age horizon per field campaign. Replicate samples were taken along the strike of the layers. Samples were shipped frozen to the University of Victoria (UVic), Canada, or OSU.

In the laboratory, we measured the methane stable carbon isotope ratio $\left(\delta^{13} \mathrm{CH}_{4}\right.$; referenced to Vienna Pee Dee Belemnite - VPDB) from occluded gas in 61 individual shaved ice samples (ca. 100-200 g). Measurements were made via an improved wet-extraction, isotope ratio mass spectrometer (IRMS) method with analytical precision $<0.3 \%$ and no introduced error or offset due to the wet extraction procedure (Melton et al., 2011). The main improvements to the procedure of Schaefer et al. (2006) and Schaefer and Whiticar (2007) include (i) a He carrier gas pre-scrubbing trap, (ii) introduction of two carbon monoxide (CO) traps, and (iii) post-combustion trapping of the methane to produce a high amplitude sample peak, increasing the signalto-noise ratio of the sample. The blank contribution was, at most, $\sim 5 \%$ of the sample signal, while more commonly $<3 \%$. Blanks were measured every two to four samples and consistently yielded a contaminant value with atmospheric $\delta^{13} \mathrm{CH}_{4}$. Following Schaefer and Whiticar (2007), sample $\delta^{13} \mathrm{CH}_{4}$ was corrected in an isotope mass balance approach using the $\mathrm{CH}_{4}$ concentration based upon $m / z 44$ peak height.

Atmospheric air tests were routinely measured at the start and end of an ice sample measurement day, as well as regularly between ice samples across a period of three years (2006, 2007, and 2009). These atmospheric air tests showed a mean $\delta^{13} \mathrm{CH}_{4}$ value of $-47.51 \pm 0.29 \%$ o $(1 \sigma ; n=48$; methane content varying between $\sim 160-830 \mathrm{pmol})$. The smallest atmospheric air samples measured $(\sim 160 \mathrm{pmol})$ did not show significantly different values and no loss in precision compared to the total dataset $(-47.50 \pm 0.18 \%$; $1 \sigma$; $n=5$ ) (Melton et al., 2011). The Påkitsoq sample with the lowest $\mathrm{CH}_{4}$ content measured contained $\sim 240 \mathrm{pmol} \mathrm{CH}_{4}$, which is well within the range measured by the atmospheric air samples. Additionally, samples of artificial reference ice were measured on most sample measurement days with a mean $\delta^{13} \mathrm{CH}_{4}$ value of $-47.51 \pm 0.29 \%$ o $(1 \sigma ; n=32$; methane content varying between $\sim 415-1080 \mathrm{pmol})$. These artificial reference ice measurements (Fig. 1) and the atmospheric air samples (Melton et al., 2011) show good linearity over the range in $\mathrm{CH}_{4}$ content found in Påkitsoq samples, as well as over the range in sample mass for reference ice samples. The precision of our method is a significant improvement from Schaefer and Whiticar (2007) as these same tests yielded reported standard deviations of $\pm 0.47 \%$ and $\pm 0.52 \%$ for atmospheric air and artificial reference ice, respectively. As well, the calculated standard deviation across our 3-yr atmospheric air and artificial ice sample dataset is slightly greater than the true analytical standard deviation because of seasonal changes of the local atmospheric 


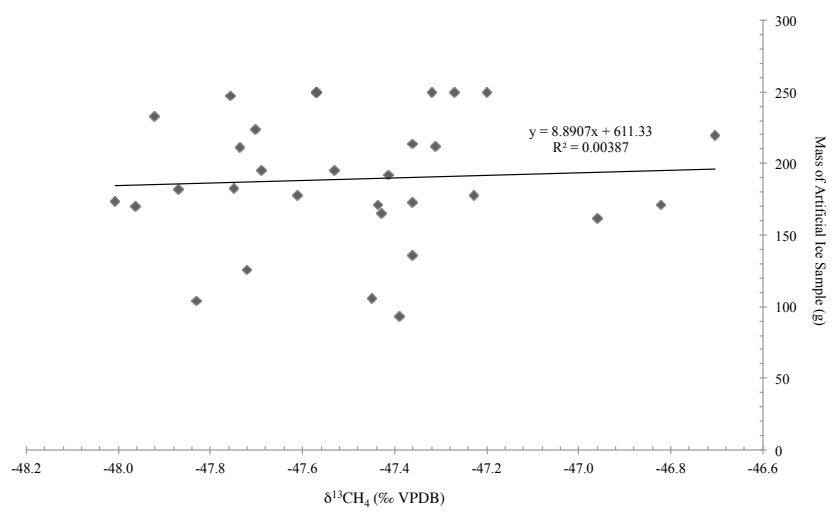

Fig. 1. Artificial reference ice samples $\delta^{13} \mathrm{CH}_{4}$ value vs. sample size across three years. The data demonstrate good linearity across the range of artificial ice sample sizes. The dataset mean $\delta^{13} \mathrm{CH}_{4}$ value is $-47.51 \pm 0.29 \%$ o $(1 \sigma ; n=32$; methane content varying between $\sim 415-1080$ pmol).

$\delta^{13} \mathrm{CH}_{4}$ used as the reference air. The seasonal change in $\delta^{13} \mathrm{CH}_{4}$ is $\pm 0.11 \%$ on the nearby Olympic Peninsula during the period from 1988 to 1995 (Quay et al., 1999). However, due to unknown offsets in $\delta^{13} \mathrm{CH}_{4}$ between Victoria and Olympic Peninsula, we do not correct for inter or intraannual variability.

Tests were also performed on the remaining pieces of a shallow section of the Greenland Ice Sheet Project II (GISP2) Core \#139 used in Schaefer and Whiticar (2007) and discussed in Melton et al. (2011). The quality of these samples is poor, with much of the ice highly fractured. The mean $\delta^{13} \mathrm{CH}_{4}$ of the GISP2 ice is $-49.37 \pm 0.58 \%$ o ( $1 \sigma$; $n=5$, corrected for gravitational fractionation) for a gas age of $\sim 225 \pm 20 \mathrm{yr} \mathrm{BP}$. Recently, Sowers (2010) published a $\delta^{13} \mathrm{CH}_{4}$ record using GISP2 ice, reporting a $\delta^{13} \mathrm{CH}_{4}$ of $-49.24 \pm 0.17 \%$ o $(1 \sigma ; n=3)$ for ice with a gas age of $\sim 200 \mathrm{yr}$ BP. The good agreement of mean values is an indicator of our accuracy, although our standard deviation is much higher than Sowers (2010). However, as fractured ice has been reported by multiple investigators to lead to spurious values (Craig et al., 1988; Schaefer and Whiticar, 2007; Behrens et al., 2008), we view our artificial ice results as more indicative of our analytical method precision than those of the GISP2 ice. Additionally, there is no indication that the artificial ice samples would somehow lead to better precision than natural ice samples given that Schaefer and Whiticar (2007) reported poorer standard deviation for their artificial ice samples $( \pm 0.52 \%$ ) than for their GISP2 samples $( \pm 0.32 \%$ ). We note that Schaefer and Whiticar (2007) used higher quality parts of the GISP2 core section, so that the difference in precision to our study does not necessarily reflect on the quality of the new technique.

The mean CF-IRMS measured methane concentration for the GISP2 Core \#139 samples is $703 \pm 43 \mathrm{ppb}(1 \sigma$; $n=5$ ). This $\mathrm{CH}_{4}$ concentration agrees reasonably well with measurements made with a conventional GC-FID from the Greenland Eurocore 235 ( $724 \pm 5 \mathrm{ppbv})$ for $\sim 217 \mathrm{yr} \mathrm{BP}$ (Etheridge et al., 1998).

As Påkitsoq ice can contain anomalous $\left[\mathrm{CH}_{4}\right]$ (Schaefer et al., 2009), samples were filtered for anomalous methane concentrations. The assessment uses two criteria for exclusion: (i) samples that showed visible post-depositional features in the ice, such as fractures; layers or occlusions of dust; or samples with bubble-free bands in the ice (Petrenko et al., 2006), and (ii) samples that had IRMS-measured $\left[\mathrm{CH}_{4}\right]$ values more than $100 \mathrm{ppb}$ different from the contemporaneous GISP2 $\left[\mathrm{CH}_{4}\right]$ (Brook et al., 2000). Sample $\left[\mathrm{CH}_{4}\right]$ for this data filter is derived by calculation against calibration curves from reference gases (serial dilutions of $\mathrm{CH}_{4}$ gas in $\mathrm{N}_{2}$ ) and air standards (1033 ppb methane (balance ultra zero air) purchased from Airgas Incorporated and calibrated at Washington State University against standard tanks previously calibrated at NOAA CMDL) (Petrenko et al., 2006) using the IRMS $m / z 44$ ion peak height (derived from the ice sample ${ }^{12} \mathrm{CH}_{4}$ ) and air content of the ice. The air content of the $\delta^{13} \mathrm{CH}_{4}$ ice samples is determined via parallel samples that were measured with GC at OSU as described in Brook et al. $(2000,2005)$ from pressure in the sample loop and ice sample volume. The standard deviation for $\left[\mathrm{CH}_{4}\right]$ measured with the IRMS is taken as the value determined using GISP2 section \#139 in our lab. Due to the poor quality of the latter, this is a conservative estimate. The $100 \mathrm{ppb}$ limit for inclusion of samples was selected by summing the magnitude of analytical standard deviation and uncertainty in the reference GISP2 $\left[\mathrm{CH}_{4}\right](\sim \pm 10 \mathrm{ppb})$ (Brook et al., 2000). This led to the removal of 21 unsuitable samples of the 61 total. For the actual $\sim 150 \mathrm{yr}$ YD-PB transition, only three anomalous samples were removed of the total 46 samples that fall within the gas age limits for inclusion in the weighted linear regression (see Fig. 2). The three suspicious samples were not considered in our subsequent source analysis (Sect. 3.3). However, the removal of those samples has no significant effect on the $\delta^{13} \mathrm{CH}_{4}$ trend across the YD-PB (Fig. 3).

For replicate measurements (multiple ice samples of equal age), median values with standard deviations are reported. For single measurements, analytical precision as derived from the artificial reference ice measurements is shown (Melton et al., 2011). All raw $\delta^{13} \mathrm{CH}_{4}$ values are presented in the Supplement in Table S1.

\subsection{Corrections to $\delta^{13} \mathrm{CH}_{4}$ values}

The YD-PB transition $\delta^{13} \mathrm{CH}_{4}$ values have been corrected for gravitational, thermal and diffusion fractionation (described below). The $\delta \mathrm{D}-\mathrm{CH}_{4}$ values of Sowers (2006) in Fig. 2 have been treated similarly. In addition, an isotopic disequilibrium correction is applied to the source reconstructions in order to account for the transient dilution effect on the source signal in the atmospheric reservoir as identified by Tans (1997) (Fig. 4). $\delta^{13} \mathrm{CH}_{4}$ values including all corrections are listed 


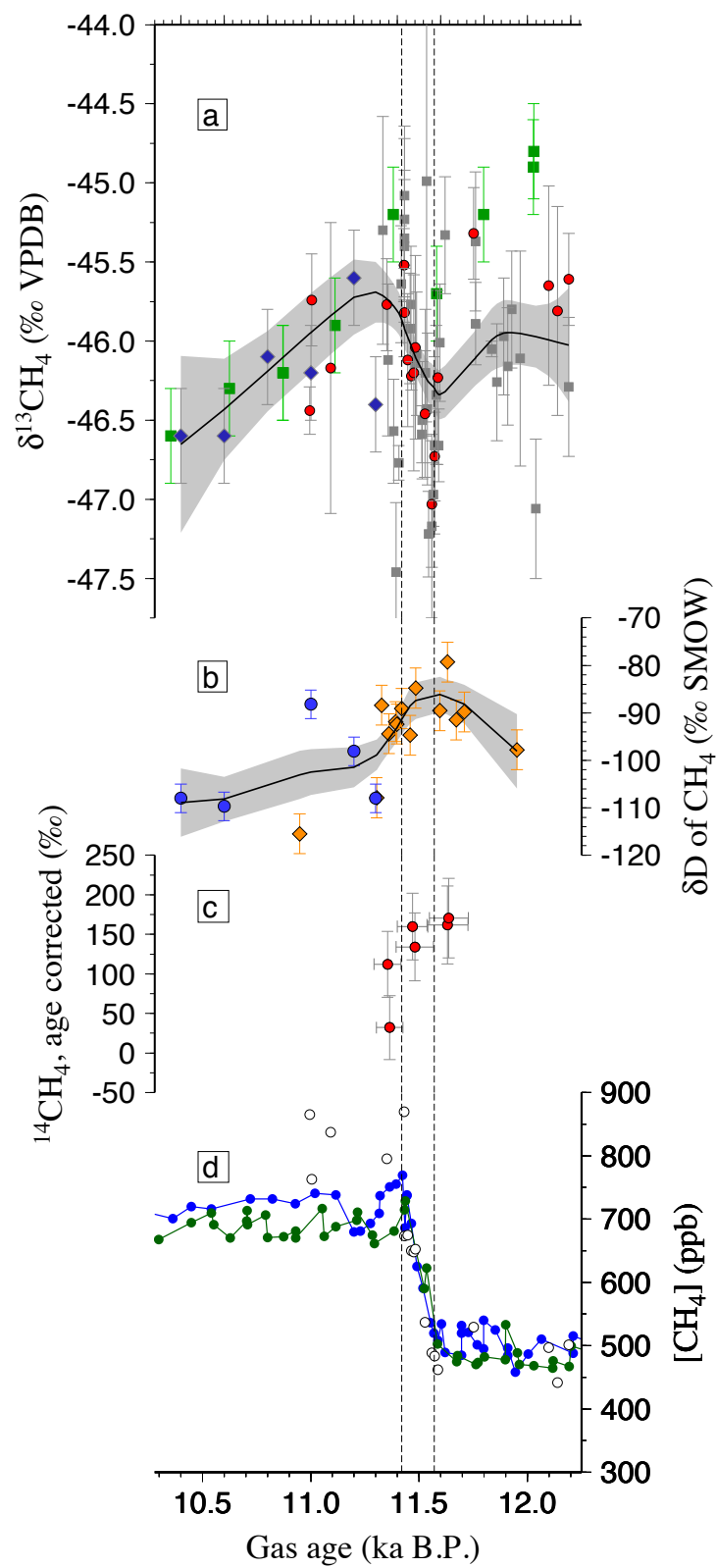

Fig. 2. The Younger Dryas to Preboreal $\delta^{13} \mathrm{CH}_{4}, \delta \mathrm{D}-\mathrm{CH}_{4},{ }^{14} \mathrm{CH}_{4}$, and $\left[\mathrm{CH}_{4}\right]$ records. (A) Påkitsoq, Greenland $\delta^{13} \mathrm{CH}_{4}$ records from this study [circles] and Schaefer et al. (2006) [grey squares] (Schaefer et al., 2006), GISP2 [blue diamonds] (Sowers, 2010), and EPICA EDML [green squares] (Fischer et al., 2008). A weighted loess spline fit to the Greenland data (Påkitsoq and GISP2, shaded region is a $1 \sigma$ standard error envelope, span 0.75) shows the general trends although it dampens the larger changes in the isotope record. (B) The $\delta \mathrm{D}-\mathrm{CH}_{4}$ record from GISP2 [circles (Sowers, 2010) and diamonds (Sowers, 2006)] with a weighted loess spline (span 0.75). (C) The ${ }^{14} \mathrm{CH}_{4}$ record from Påkitsoq, Greenland (cosmogenic ${ }^{14} \mathrm{C}$ corrected values) (Petrenko et al., 2009). (D) $\left[\mathrm{CH}_{4}\right]$ records from GISP2 [blue] (Brook et al., 2000), EDML [green] (EPICA Community Members, 2006), and Påkitsoq IRMS [open circles]. The latter record has lower precision. All data are shown using the revised Pak06 age scale (Sect. 2.2.5). The vertical dashed lines show the YD-PB limits.

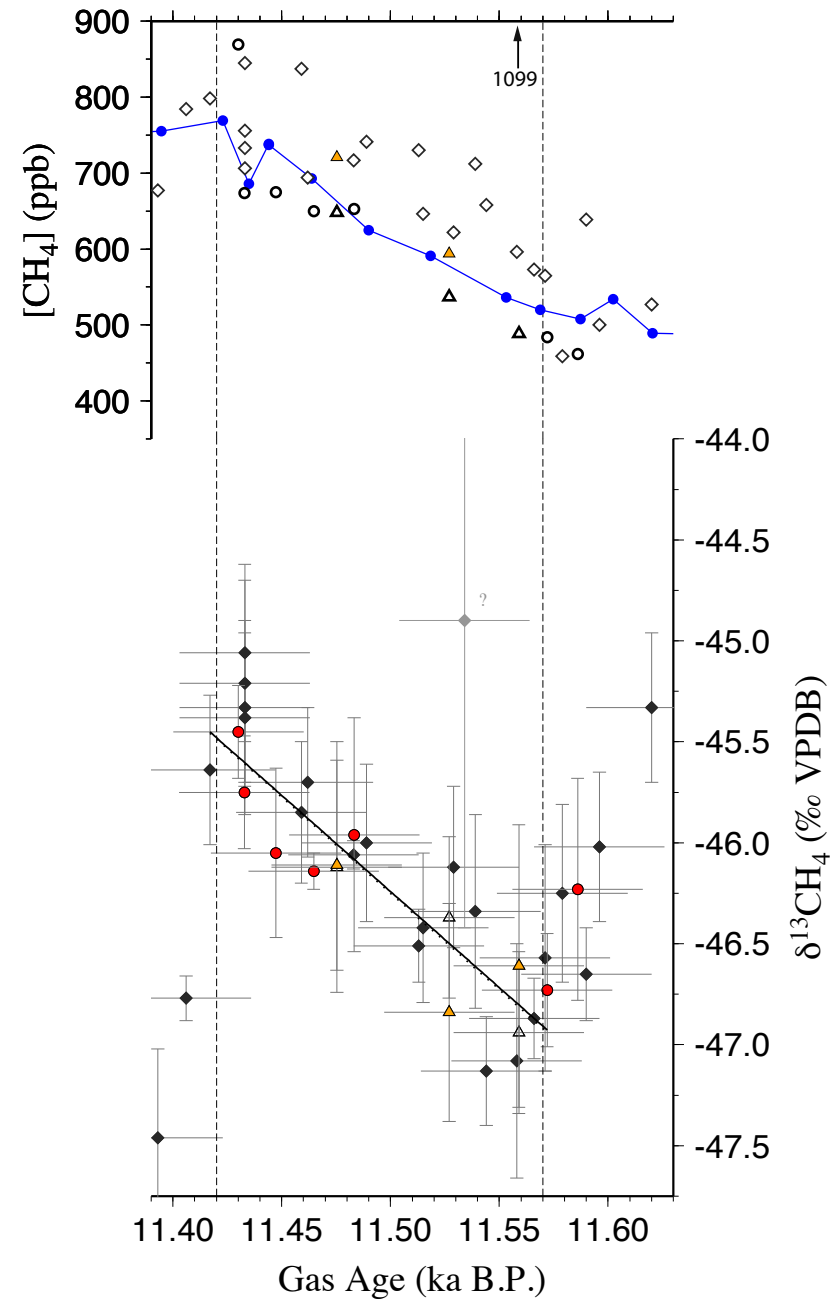

Fig. 3. The $\delta^{13} \mathrm{CH}_{4}$ record for the YD-PB including the three samples removed using the data filter. The bottom panel shows $\delta^{13} \mathrm{CH}_{4}$ values from this study (red circles and triangles) and Schaefer et al. (2006) corrected for gravitational, diffusional and thermal fractionation. The data points, both with those 3 anomalous samples removed [open triangles], and included [yellow triangles] are plotted. The weighted linear regression for the entire dataset [dashed line] plots almost on top of the regression for the filtered dataset [solid line]. This demonstrates that the data filter has effectively no effect on the calculated change in the $\delta^{13} \mathrm{CH}_{4}$ value across the YD-PB. The top panel is the $\left[\mathrm{CH}_{4}\right]$ records from GISP2 [blue line] (Brook et al., 2000), Schaefer et al. (2006) [open diamonds], and this study. For our data, open circles indicate data points not influenced by the data filter, open triangles are data points that exclude anomalous samples, and yellow triangles include all samples. One value that plots off the scale of the $y$-axis is indicated by an arrow. The vertical dashed lines show the limits of the YD-PB. 


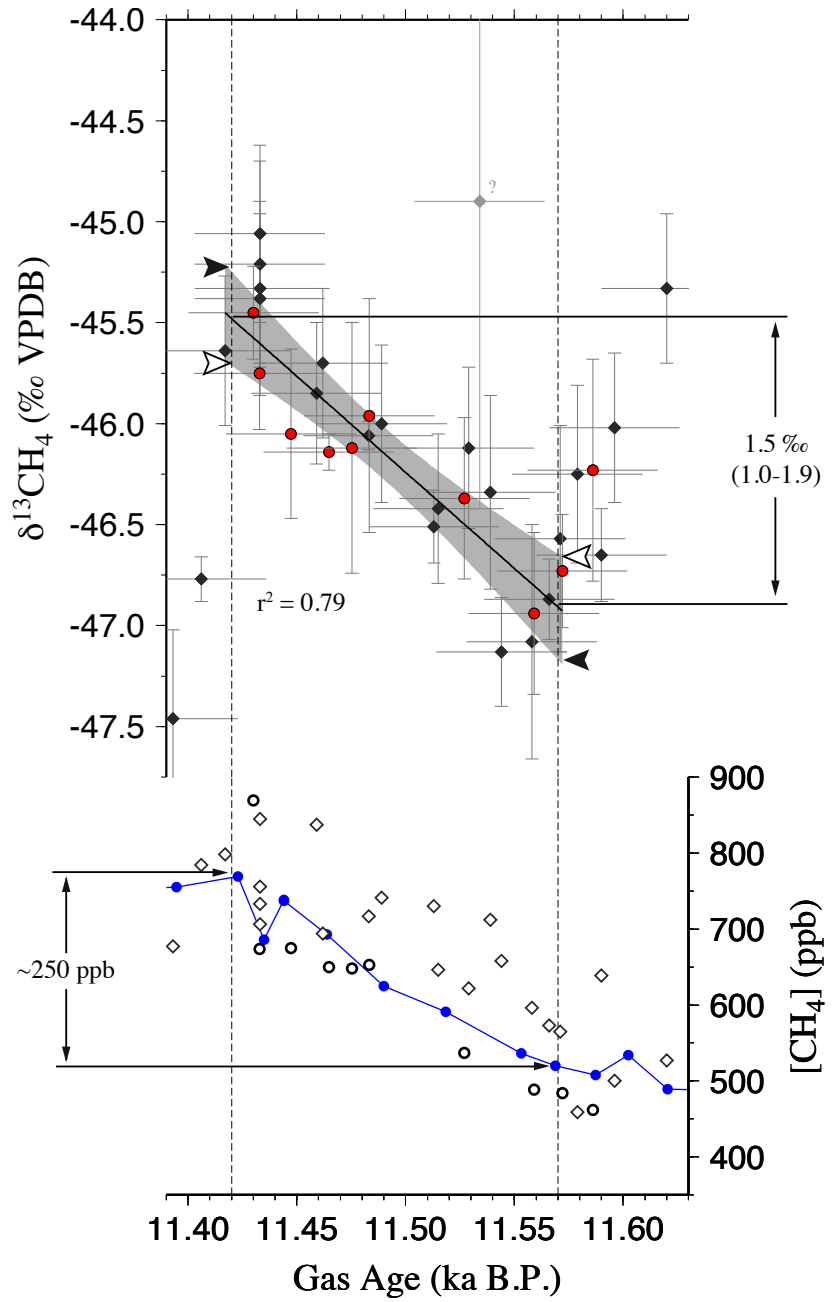

Fig. 4. The YD-PB equilibrated atmospheric $\delta^{13} \mathrm{CH}_{4}$ and $\left[\mathrm{CH}_{4}\right]$ record from Påkitsoq ice samples. The top panel shows the isotopic disequilibrium corrected $\delta^{13} \mathrm{CH}_{4}$ from this study [circles] and Schaefer et al. (2006) [diamonds]. The data are fit with a weighted linear regression between the gas ages of the last low $\left[\mathrm{CH}_{4}\right]$ value and the peak $\left[\mathrm{CH}_{4}\right]$ value in the GISP2 record (shaded region is the $99 \%$ model fit confidence interval). The $\delta^{13} \mathrm{CH}_{4}$ value range is found from the model confidence interval's minimum [unfilled arrowheads] and maximum [filled arrowheads] differences. The estimated range in age per sample is ca. 25-35 yr (indicated as uncapped horizontal bars), which includes both sample thickness and gas age distribution due to diffusion and bubble enclosure (Schaefer et al., 2006). Bottom panel: $\left[\mathrm{CH}_{4}\right]$ records from GISP2 [blue line] (Brook et al., 2000) and Påkitsoq (open circles [this study] and diamonds - Schaefer et al., 2006).

in the Supplement in Table S2. The European Project for Ice Coring in Antarctica (EPICA) ice core $\delta^{13} \mathrm{CH}_{4}$ data from Dronning Maud Land (EDML) shown in Fig. 2 include their own gravitational fractionation correction (Fischer et al., 2008). As these values do not fall directly within the YD$\mathrm{PB}$, they do not require further correction (see further discussion in Sect. 3.2).

\subsubsection{Gravitational and thermal fractionation}

$\delta^{15} \mathrm{~N}$ of $\mathrm{N}_{2}$ as measured at Scripps Institute of Oceanography (Petrenko et al., 2006) on parallel samples records approximately the same gravitational and thermal fractionation as $\mathrm{CH}_{4}$ isotopes in the firn column prior to bubble closeoff. For the thermal fractionation component of this correction, we neglect different thermal diffusivities, $\Omega_{\mathrm{T}}$, of the isotopes of $\mathrm{N}_{2}$ and $\mathrm{CH}_{4}$ in air (Grachev and Severinghaus, 2003). The latter has not been determined experimentally for $\mathrm{CH}_{4}$, but $\Omega_{\mathrm{T}}$ of ${ }^{13} \mathrm{CH}_{4}$ in ${ }^{12} \mathrm{CH}_{4}$ (Stevens and de Vries, 1968) suggests that the difference to $N_{2}$ isotopes is on the order of $\sim 12 \%$ (Schaefer, 2005). The thermal component of the $\delta^{15} \mathrm{~N}$ anomaly over the YD-PB termination is only $\sim 0.15 \%$ o (Severinghaus et al., 1998). Therefore, the error from different $\Omega_{T}$ is likely around $0.02 \%$ with an uncertainty of a fraction of that value.

\subsubsection{Diffusion fractionation}

$\delta^{13} \mathrm{CH}_{4}$ and $\delta \mathrm{D}-\mathrm{CH}_{4}$ values that have a gas age within the YD-PB transition, i.e. during periods of rapid and large atmospheric $\left[\mathrm{CH}_{4}\right]$ change, require correction for fractionation during firn diffusion processes. Under changing atmospheric concentrations, the atmospheric signal of the heavier methane stable isotopologue will diffuse to the firn closeoff zone more slowly than the light methane stable isotopologue (Trudinger et al., 1997). We quantified correction factors with a firn diffusion model (Schaefer, 2005) based upon other models (Herron and Langway, 1980; Schwander et al., 1993, 1997) that calculate the effective diffusion coefficients for each isotopologue from physical properties of the firn on dependence of local temperature and accumulation rate. The applied correction factors are substantial (up to $0.7 \%$ ). However, sensitivity tests for environmental conditions (temperature and accumulation rate) and model input parameters (Schaefer, 2005) show that our observed trend in $\delta^{13} \mathrm{CH}_{4}$ values is not an artefact of the diffusion model. The sensitivity tests quantify the absolute uncertainty as less than $0.2 \%$ (Schaefer, 2005).

\subsubsection{Isotopic disequilibrium}

A rapid change in atmospheric methane concentration and/or stable isotope values causes a temporary imbalance between stable isotope values of the atmosphere and that of the aggregated sources as predicted at steady-state after sink fractionation (Tans, 1997; Lassey et al., 2000). Accounting for isotopic disequilibrium is important if measured atmospheric stable isotope values are used to interpret methane sources during a period of rapid changes. We therefore calculated appropriate corrections using a 2-box atmospheric model (Lassey et al., 2000) that includes source, sink and interhemispheric transport terms. Isotopologues are treated as independent tracers, and the atmospheric isotope ratio is 
calculated for each time step ( $1 \mathrm{yr}$ ). The model simulates the 150-yr-long transition from a YD to a Preboreal source and sink budget taken from isotope-enabled 4-box atmospheric methane model simulations (Melton, 2010). Discrete correction factors are calculated for each data point by matching the corresponding $\left[\mathrm{CH}_{4}\right]$ values in the modelled and observed $\left[\mathrm{CH}_{4}\right]$ increase. The correction is small with maximum values of $0.09 \%$ for $\delta^{13} \mathrm{CH}_{4}$ and $2.67 \%$ for $\delta \mathrm{D}-\mathrm{CH}_{4}$ (Table S2 in the Supplement).

\subsubsection{Systematic offset between datasets}

The values of Schaefer et al. (2006) have been adjusted for this study to account for a systematic offset from our new measurements. Measurements of outside air at UVic by the method of Schaefer et al. (2006) as described in Schaefer and Whiticar (2007) $(-47.33 \pm 0.47 \%$ o $)$ and our method $(-47.51 \pm 0.21 \%$ o (Melton et al., 2011) show a $0.18 \%$ offset. Schaefer and Whiticar (2007) also reported a $0.18 \%$ offset from a high-precision dataset of clean air measured on the nearby Olympic Peninsula (Quay et al., 1999), while our method showed no offset. Despite the fact that all three datasets were measured at different times and the seasonal $\delta^{13} \mathrm{CH}_{4}$ cycle introduces uncertainty, we take this as an indication that the values of Schaefer et al. (2006) have to be adjusted to remove the offset through a simple linear addition. One anomalous point from the Schaefer et al. (2006) dataset has been excluded from the linear regression applied to the $\delta^{13} \mathrm{CH}_{4}$ values during the YD-PB (Figs. 3 and 4). This is because a $\delta^{13} \mathrm{CH}_{4}$ shift of that magnitude and speed is not possible due to firn diffusion processes.

\subsubsection{Påkitsoq age scale}

Field measurements of $\left[\mathrm{CH}_{4}\right]$ (Brook et al., 2000) were used to correlate the basic stratigraphy to that of GISP2 for ice sampling (Petrenko et al., 2006). To establish the age of the air bubbles within the Påkitsoq ice, we match geochemical records measured in Påkitsoq ice to those of well-dated ice cores from locations that are comparable in geography, as well as temperature and accumulation rate, to the snow deposition zone for Påkitsoq ice. Four reference records are used to determine the age scale of the Påkitsoq ice: (i) $\delta^{15} \mathrm{~N}$ of atmospheric $\mathrm{N}_{2}$ (Severinghaus et al., 1998), (ii) $\delta^{18} \mathrm{O}_{\text {ice }}$ from the ice matrix (Grootes and Stuiver, 1997), (iii) $\left[\mathrm{CH}_{4}\right]$ (Brook et al., 2000), all from GISP2, Greenland, and (iv) $\delta^{18} \mathrm{O}_{\text {atm }}$ of atmospheric $\mathrm{O}_{2}$ from Siple Dome, Antarctica (Severinghaus et al., 2009). The $\delta^{18} \mathrm{O}_{\text {atm }}$ value is globally well-mixed, and has been measured with high temporal resolution and analytical precision (Severinghaus et al., 2009). This dataset (from Siple Dome, Antarctica) is chosen over the current GISP2 dataset (Bender et al., 1999), due to its greater precision and inclusion of a gas-loss correction. $\delta^{15} \mathrm{~N}$ is the most consistent parameter between GISP2 and Påkitsoq, implying similar temperature and accumulation rates between the sites. This close correlation is found across all years and sampling locations (Melton, 2010). Thus, this parameter is relied upon extensively for age assignments. Due to the much improved $\delta^{18} \mathrm{O}_{\text {atm }}$ record, this parameter is used more extensively in this work than previously (Petrenko et al., 2006; Schaefer et al., 2006). The Siple Dome record (Severinghaus et al., 2009) has a very high precision (pooled standard deviation after gas-loss correction of $\pm 0.012 \%$ o); however, the Påkitsoq measurement precision is not as good $\left( \pm 0.028 \%\right.$ o) (Petrenko et al., 2006). Therefore, the $\delta^{18} \mathrm{O}_{\mathrm{atm}}$ values are used as a secondary constraint on age tie- points set by the $\delta^{15} \mathrm{~N}$ data. The $\delta^{15} \mathrm{~N}$ data have peaks with similar $\delta^{15} \mathrm{~N}$ values on both sides of the peak, and thus two possible ages. The $\delta^{18} \mathrm{O}_{\text {atm }}$ values are then used to provide a secondary constraint of the age. The inflection points in the $\left[\mathrm{CH}_{4}\right]$ record provide excellent tie-points for the onset and end of climatic transitions. For example, they indicate the start (together with a peak in $\delta^{15} \mathrm{~N}$ ) and the end of the YDPB. We use Påkitsoq $\left[\mathrm{CH}_{4}\right]$ data with high analytical precision measured by GC-FID at OSU (Petrenko et al., 2006) for the correlations. The $\delta^{18} \mathrm{O}_{\text {ice }}$ parameter is used when the other parameters do not exhibit sufficiently unique features for an age determination. To account for the ice thinning and folding, the age scale is variable along the sampling profile. Fourteen age tie-points were used to create a continuous age scale (Table S3 in the Supplement) with linear interpolation between tie-points (Melton, 2010) for the 2001 sampling season. This 2001 sampling season age scale was then adapted for changes in the ice due to surface melt each sampling season on the basis of shifts in the horizontal positions of the geochemical markers referenced to the permanent markers left in the ice. Age uncertainty close to, and within, the YD$\mathrm{PB}$ is estimated to be better than $1 \%$ absolute uncertainty (Petrenko et al., 2006).

The absolute gas age scale (GISP2 depth to calendar age) used is that of Schaefer et al. (2006). This age scale differs from the common GISP2 gas age scale of Brook et al. (2000) by fixing the date of the YD termination to $11570 \pm 0 \mathrm{yr} B P$ on the basis of tree ring records (Friedrich et al., 1999). All literature datasets presented in this study are converted to this age scale. The EDML dataset was converted to the Påkitsoq timescale by performing a linear regression on both of the GISP2 and EDML $\left[\mathrm{CH}_{4}\right]$ records during only the abrupt $\left[\mathrm{CH}_{4}\right]$ increase, and adjusting the EDML gas ages to allow the lines to overlap. This fitting and placement on the Påkitsoq timescale required an addition of $134 \mathrm{yr}$ (no compression or expansion of the timescale was performed) to the GICC05 age of EDML points.

As both sample thickness and the gas age distribution due to diffusion and bubble enclosure contribute to an age range per sample, our per sample estimated range in age is $\sim 25$ $35 \mathrm{yr}$. 


\section{Results}

The $\delta^{13} \mathrm{CH}_{4}$ data are plotted in Fig. 2 on a common age scale with previous Påkitsoq data (Schaefer et al., 2006). The Schaefer et al. (2006) Påkitsoq dataset includes ice with an uneven distribution of gas age from each of the 2001-2003 sampling seasons (particularly at the start of the YD-PB) (Schaefer et al., 2006). In contrast, the combination of our dataset and the Schaefer et al. (2006) dataset now provides replicate samples over multiple field campaigns (2001-2005) for each part of the record to minimize sampling biases and analytical uncertainty. The combined record contains 43 individual samples with gas ages within the $\sim 150 \mathrm{yr}$ YD-PB.

Comparing the combined Påkitsoq $\delta^{13} \mathrm{CH}_{4}$ dataset to the published records from the EDML core (Fischer et al., 2008) and GISP2 (Sowers, 2010) shows good agreement in the Preboreal period with all records showing a general pattern towards more ${ }^{13} \mathrm{C}$-depleted values as the $\mathrm{PB}$ progresses (Fig. 2). Looking at the YD period, there is a greater divergence between the Påkitsoq and EDML records (Fischer et al., 2008) with the Påkitsoq values generally more ${ }^{13} \mathrm{C}$ depleted (and possibly with higher scatter than in the PB period). This could indicate that the inter-hemispheric $\delta^{13} \mathrm{CH}_{4}$ gradient was greater in the YD than in the PB period. However, any interpretations of the magnitude of offset between datasets should be tempered by uncertainties due to (i) higher uncertainties in the age-scales outside the rapid transitions, and (ii) the inter-laboratory offset between the measurement labs. The inter-laboratory offset could be influenced by several factors including blank corrections, standard gases, and instrumental drift corrections. However, an inter-laboratory offset would result in a constant offset that influences the magnitude of the offset between datasets, but not the general pattern of each dataset. As a result, we will limit our discussion to the general pattern displayed by each dataset and not attempt to interpret the magnitude or changes in offset between datasets.

\subsection{Observed Trend in $\delta^{13} \mathrm{CH}_{4}$ values across the YD-PB}

Throughout the late YD and early PB periods, while $\left[\mathrm{CH}_{4}\right]$ was stable, there is a trend of ${ }^{13} \mathrm{CH}_{4}$ depletion (Fig. 2) that has been observed previously (Fischer et al., 2008). In contrast, the fast YD-PB $\left[\mathrm{CH}_{4}\right]$ rise coincides with strong enrichment in ${ }^{13} \mathrm{CH}_{4}$ that reverses the long-term ${ }^{13} \mathrm{CH}_{4}$ evolution. Outside of the transition, there appears to be relatively large movements in the $\delta^{13} \mathrm{CH}_{4}$ values without a corresponding large change in atmospheric $\left[\mathrm{CH}_{4}\right]$. This phenomenon has been observed in other studies (Bock et al., 2010; Möller et al., 2012). Changes in $\delta^{13} \mathrm{CH}_{4}$ values without significant changes in atmospheric $\left[\mathrm{CH}_{4}\right]$ could be caused by changes in the ratios of the different sources and sinks or even changes in the characteristic isotope values of the sources and sinks themselves due to changing environmental conditions or some unknown processes. While these changes are of interest, for this paper, we will focus our interpretation on the termination of the YD-PB as this period has a large increase in methane concentration coincident with dramatic changes in climate. We use the $\delta^{13} \mathrm{CH}_{4}$ increase to delineate the driving processes of $\left[\mathrm{CH}_{4}\right]$ rise at the YD-PB. We focus on the methane budgets at the start and end of the $\left[\mathrm{CH}_{4}\right]$ rise to (i) minimize uncertainties due to fractionation that gases and their isotopologues undergo as they move through the unconsolidated snow (firn) prior to bubble close-off, and (ii) avoid transient signals, such as diffusional smoothing (see Sect. 2.2.2.). The change in $\delta^{13} \mathrm{CH}_{4}$ across the YD-PB $\left(\Delta \delta^{13} \mathrm{CH}_{4}\right.$ ) shows a mean ${ }^{13} \mathrm{C}$-enrichment of $1.5 \%$ for the combined dataset as determined by a weighted linear regression with a $99 \%$ confidence interval (CI) range of 1.0 to $1.9 \%$ (Fig. 4). This is a conservative estimate of $\Delta \delta^{13} \mathrm{CH}_{4}$ because gas diffusion in the firn dampens the excursions that form the beginning and end of the reversal in the ice record and therefore smoothes the signal of atmospheric changes. The measured Påkitsoq $\Delta \delta^{13} \mathrm{CH}_{4}$ over the $\sim 150 \mathrm{yr}$ transition is similar in magnitude to the $\sim 2 \%{ }^{13} \mathrm{C}$-enrichment from 1850 to $2000 \mathrm{AD}$ (Sowers, 2010), despite the absence of anthropogenic sources.

\subsection{Robustness of the findings}

Påkitsoq ice is known to sporadically produce anomalously high results for $\left[\mathrm{CH}_{4}\right]$ as compared to contemporary GISP2 ice (Petrenko et al., 2006; Schaefer et al., 2009). It is therefore necessary to test whether the finding of the ${ }^{13} \mathrm{C}$ enrichment trend is robust. It can be shown that, although excess $\left[\mathrm{CH}_{4}\right]$ may lead to lower precision and introduce uncertainty, it does not systematically affect $\delta^{13} \mathrm{CH}_{4}$ in the Påkitsoq ice (Schaefer et al., 2006). For the presented data, the maximal values of $\left[\mathrm{CH}_{4}\right]$ excess reach up to $480 \mathrm{ppb}$ with two extreme values $>1000 \mathrm{ppb}$ (defined as the difference between Påkitsoq IRMS-derived [ $\left.\mathrm{CH}_{4}\right]$ and GISP2 (Brook et al., 2000)). This is clearly higher than the conservative estimate of our $\left[\mathrm{CH}_{4}\right]$ precision $( \pm 43 \mathrm{ppb})$ and excess values span three orders of magnitude, yet excess $\left[\mathrm{CH}_{4}\right]$ and $\delta^{13} \mathrm{CH}_{4}$ are not correlated with $r^{2}=0.092$ (Fig. 5). Even if there was a systematic effect of excess $\left[\mathrm{CH}_{4}\right]$ on $\delta^{13} \mathrm{CH}_{4}$, the former would have to affect certain parts of the record more than others in order to create an artifactual trend. This is not evident with $r^{2}$ values for age versus $\left[\mathrm{CH}_{4}\right]$ excess over the ca. $150 \mathrm{yr}$ transition period of 0.02 and 0.01 , with and without two major outliers $\left(\left[\mathrm{CH}_{4}\right]\right.$ excess $\left.>1000 \mathrm{ppb}\right)$, respectively (Fig. 5). We cannot rule out that the lower-thanstandard precision of our method for $\left[\mathrm{CH}_{4}\right]$ masks a minor trend in $\left[\mathrm{CH}_{4}\right]$ excess. However, due to the lack of correlation between $\delta^{13} \mathrm{CH}_{4}$ and the large range of detected $\left[\mathrm{CH}_{4}\right]$ excess, we consider it unlikely that such a masked trend in $\left[\mathrm{CH}_{4}\right]$ excess would cause the observed ${ }^{13} \mathrm{C}$-enrichment trend. We also note that in Påkitsoq ice $\left[\mathrm{CH}_{4}\right]$ excess is more prevalent in ice from warm periods than in cold ones (Schaefer et al., 2009). As in situ produced $\mathrm{CH}_{4}$ is expected to 

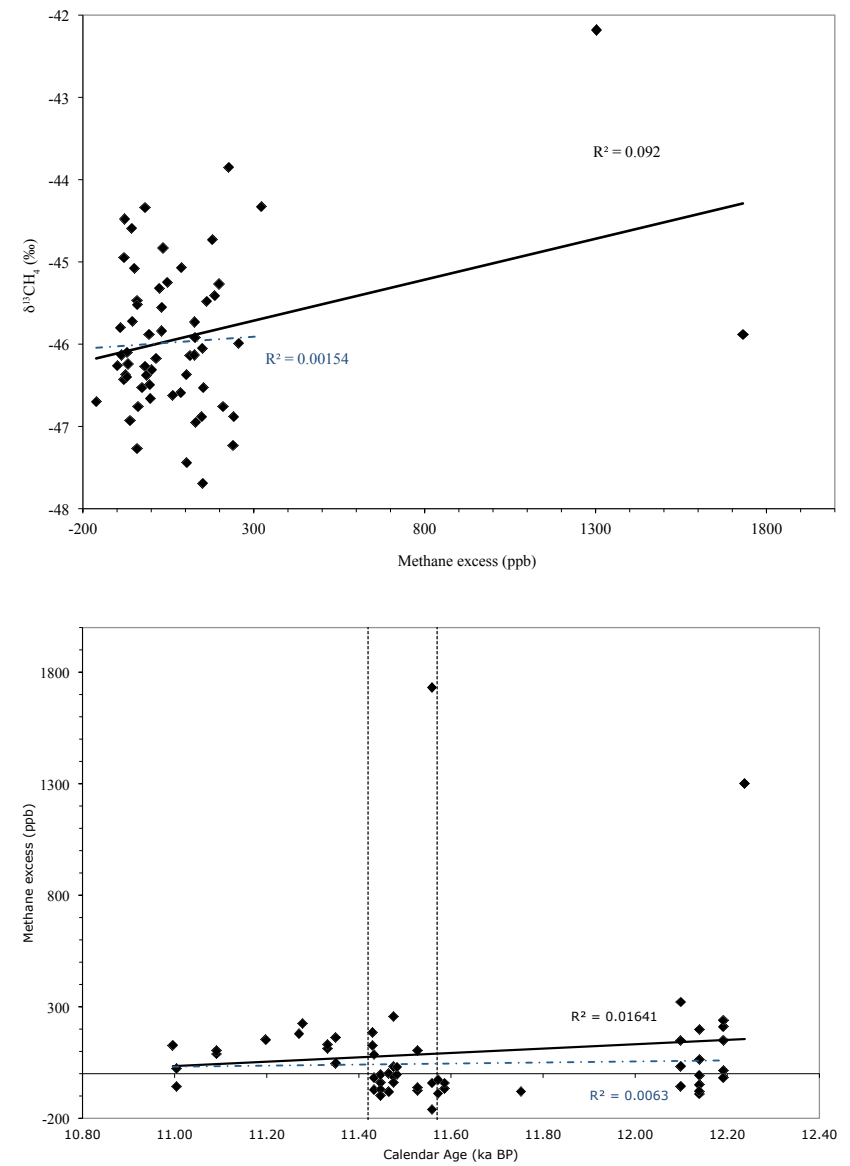

Fig. 5. Påkitsoq excess $\mathrm{CH}_{4}$ plotted against gas age and $\delta^{13} \mathrm{CH}_{4}$ values. Excess $\mathrm{CH}_{4}$ is defined as the difference between Påkitsoq IRMS-derived $\left[\mathrm{CH}_{4}\right]$ and GISP2 (Brook et al., 2000). Linear trend lines and $r^{2}$ values are shown considering all points (solid black) or all points excluding the two major outliers $\left(>1000 \mathrm{ppb} \mathrm{CH}_{4}\right.$ excess)(dashed blue). Top panel: $\delta^{13} \mathrm{CH}_{4}$ value as a function of methane excess. Bottom panel: methane excess as a function of gas age. The vertical dashed lines denote the start and end of the YD-PB transition as shown in Figs. 1 and 2.

be ${ }^{13} \mathrm{C}$-depleted due to the metabolic fractionation during methanogenesis (Whiticar, 1999), we would anticipate lower $\delta^{13} \mathrm{CH}_{4}$ in the contamination prone PB ice compared to YD ice. The observed trend in our record is of opposite sign, so it is unlikely to be a natural artefact from in situ $\mathrm{CH}_{4}$ production in the ice.

We further note that the magnitude of the enrichment $(1.5 \%$ ) clearly exceeds analytical precision $(< \pm 0.3 \%$ o (Melton et al., 2011) and pooled standard deviation $( \pm 0.56 \%$ ) of our new dataset (including points removed by the data filter). The $99 \% \mathrm{CI}$ of the trend, which is weighted by data uncertainty, shows that the trend is statistically significant with a minimum enrichment of $1.0 \%$. The reversal to higher $\delta^{13} \mathrm{CH}_{4}$ is also not dependent on the applied data filter as it is evident in both the filtered and unfiltered datasets with almost identical magnitudes (Fig. 3). Additionally, the sum

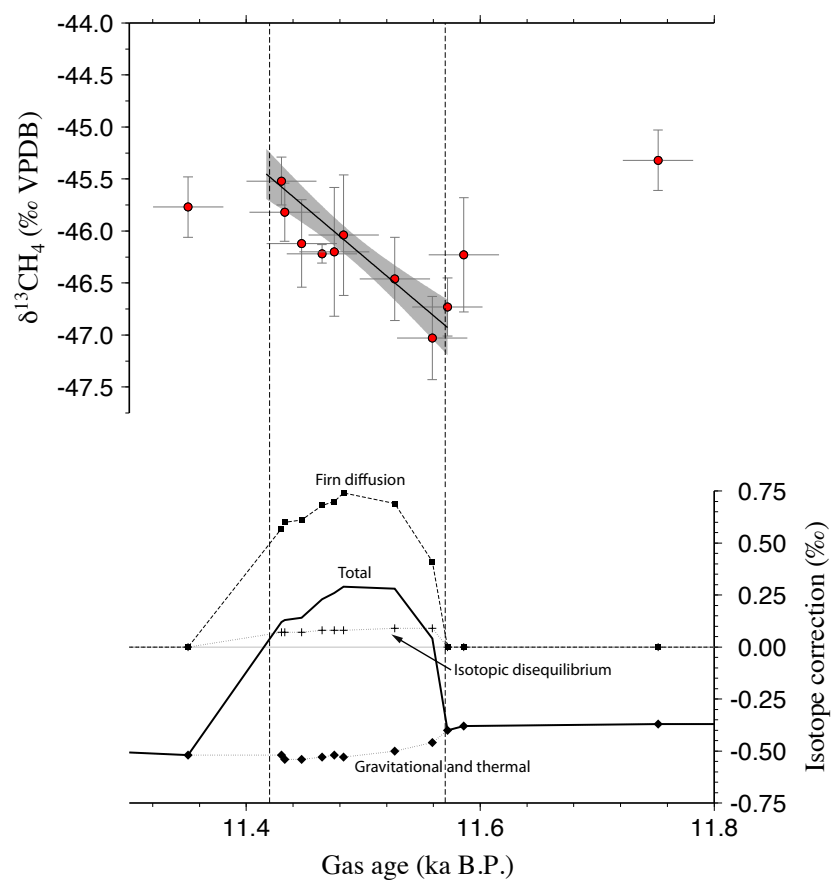

Fig. 6. The gravitational, thermal, diffusion, and isotopic equilibrium isotope corrections for the Påkitsoq $\delta^{13} \mathrm{CH}_{4}$ record. The upper panel is the Påkitsoq $\delta^{13} \mathrm{CH}_{4}$ record from this study - the Schaefer et al. (2006) values were treated identically but are not plotted here for clarity. The linear regression model (as in Fig. 2) using Påkitsoq data points from the combined dataset (this study and Schaefer et al., 2006) is shown. The bottom panel shows the isotope corrections as applied to each data point.

of all applied fractionation corrections (Sect. 2.2.) takes the form of a flat-topped peak that is distinct from the near linear ${ }^{13} \mathrm{CH}_{4}$ trend across the YD-PB (Fig. 6), i.e. uncertainties in the applied corrections cannot account for the trend. We conclude that the enrichment is a statistically significant and robust feature of our dataset.

Two previously published $\delta^{13} \mathrm{CH}_{4}$ studies covering the same time period have not reported an enrichment trend during the YD-PB. A closer look at the published data, however, reveals evidence for the enrichment in those records. The mean $\delta^{13} \mathrm{CH}_{4}$ values of the Schaefer et al. (2006, Fig. 1) dataset show a continuous development to more ${ }^{13} \mathrm{C}$ enriched values throughout the YD-PB, where the $\delta^{13} \mathrm{CH}_{4}$ values at the end of the $\left[\mathrm{CH}_{4}\right]$ rise exceed those at the start by a margin bigger than the combined uncertainties. The authors did not state a trend, mostly because the start of the transition was represented by samples from only one field season, which does not cover the preceding YD. This introduced the possibility of a sampling bias. The combined Påkitsoq dataset now shows that the feature is reproducible in sample sets from various campaigns. Schaefer et al. (2006) also presented high precision $\delta^{13} \mathrm{CH}_{4}$ measurements on large volume samples performed on a different experimental setup 
Table 1. Carbon and hydrogen isotope fractionation factors and proportional strength values for the $\mathrm{CH}_{4}$ sink terms used in the mass balance calculations. The standard scenario with a weak MBL is denoted in bold font. Alternative values tested are shown in parentheses.

\begin{tabular}{|c|c|c|c|c|c|c|}
\hline \multirow[t]{2}{*}{ Sink } & \multirow{2}{*}{$\begin{array}{l}\varepsilon_{\mathrm{C}} \\
(\% \circ \mathrm{VPDB})\end{array}$} & \multirow{2}{*}{$\begin{array}{r}\varepsilon_{\mathrm{D}} \\
(\% \text { VSMOW })\end{array}$} & \multicolumn{4}{|c|}{ Sink Fractional Strength } \\
\hline & & & No $\mathrm{MBL}^{2}$ & $\begin{array}{c}\text { Weak } \\
\text { MBL }^{4}\end{array}$ & $\begin{array}{r}\text { Mean } \\
\text { MBL }^{4}\end{array}$ & $\begin{array}{l}\text { Strong } \\
\text { MBL }^{4}\end{array}$ \\
\hline $\begin{array}{l}\text { OH oxidation } \\
\left(-4.65^{3}\right)\end{array}$ & $\begin{array}{l}-3.9^{\mathrm{a}} \\
\left(-5.4^{1}\right)\end{array}$ & $-231^{b}$ & $\begin{array}{l}0.879 \\
\left(0.838^{3}\right)\end{array}$ & 0.860 & 0.843 & 0.827 \\
\hline Soil uptake & $\begin{array}{l}-\mathbf{2 2}^{\mathrm{c}} \\
\left(-20^{3}\right)\end{array}$ & $-\mathbf{8 0}^{\mathrm{d}}$ & $\begin{array}{l}0.052 \\
\left(0.051^{3}\right)\end{array}$ & 0.051 & 0.050 & 0.049 \\
\hline Stratospheric loss & $\begin{array}{l}-\mathbf{1 2}^{\mathrm{e}} \\
\left(-3^{3}\right)\end{array}$ & $-160^{f}$ & $\begin{array}{l}0.062 \\
\left(0.068^{3}\right)\end{array}$ & 0.067 & 0.066 & 0.065 \\
\hline $\begin{array}{l}\text { Atomic chlorine in } \\
\text { the marine boundary } \\
\text { layer }\end{array}$ & $\begin{array}{l}-\mathbf{6 6}^{\mathrm{g}} \\
\left(-60^{3}\right)\end{array}$ & $-474^{\mathrm{h}}$ & $\begin{array}{l}0 \\
\left(0.042^{3}\right)\end{array}$ & 0.022 & 0.041 & 0.060 \\
\hline
\end{tabular}

\footnotetext{
${ }^{a}$ Saueressig et al. (2001), ${ }^{\mathrm{b}}$ Gierczak et al. (1997), ${ }^{\mathrm{c}}$ King et al. (1989), Tyler et al. (1994), Reeburgh et al. (1997), ${ }^{\mathrm{d}}$ Snover and Quay (2000), ${ }^{\mathrm{e}}$ Wahlen et al. (1989a), Brenninkmeijer et al. (1995), ${ }^{\mathrm{f}}$ Irion et al. (1996), ${ }^{\mathrm{g}}$ Saueressig et al. (1995), ${ }^{\mathrm{h}}$ Tyler et al. (2000)

${ }^{1}$ Alternative value by Cantrell et al. (1990) used by Fischer et al. (2008). ${ }^{2}$ Proportional sink strengths are in line with estimates in Denman et al. (2007). ${ }^{3}$ Values from Lassey et al. (2007). ${ }^{4}$ Proportional sink strengths are adjusted to accommodate the modern estimated sink strength of Allan et al. (2007) mean, low and high estimates.
}

(Ferretti et al., 2005). These values integrate over long time spans and therefore present a strongly muted version of the atmospheric signal, but qualitative ${ }^{13} \mathrm{C}$-enrichment is evident (Schaefer et al., 2006, Fig. 1), although it may not be statistically significant. The $\delta^{13} \mathrm{CH}_{4}$ record from EDML, Antarctica, shows a near continuous ${ }^{13} \mathrm{C}$-depletion trend from the start of the YD that persists far into the PB (Fischer et al., 2008). However, the record does not resolve the YD-PB in detail and presents only values before and after (but not during) the rapid $\left[\mathrm{CH}_{4}\right]$ increase (see further discussion below). The two bracketing values show the only reversal of the longterm depletion trend with an enrichment of $0.5 \%$ (Fig. 2). This value is significant with respect to the stated data uncertainty $( \pm 0.15 \%$ ).

One of the EDML $\delta{ }^{13} \mathrm{CH}_{4}$ data points has a mean gas age (on the Påkitsoq timescale) of little more than a decade prior to the initiation of the rapid $\mathrm{CH}_{4}$ transition. While we feel that our age determination is based upon the best approach available (see Sect. 2.2.5), given the uncertainty in gas ages, it is possible that the EDML sample falls within the abrupt $\mathrm{CH}_{4}$ transition. If so, that data point would require correction for diffusion fractionation, giving a possible correction of between 0 and almost $1 \%$ (Buizert, 2012). Where exactly in that range the appropriate correction lies depends on how well the exact start of the abrupt $\left[\mathrm{CH}_{4}\right]$ rise can be determined. The Greenland records (GISP2 and Påkitsoq) have an advantage with detailed $\left[\mathrm{CH}_{4}\right]$ and $\delta^{15} \mathrm{~N}$ records (Severinghaus et al. 1998), while the EDML $\left[\mathrm{CH}_{4}\right]$ record is relatively sparse (EPICA Community Members, 2006) and lacking a good gas phase indicator of the initiation of the warming event. Regardless, Buizert (2012) applied diffusion correction to the data point in question, which creates a plateau in the EDML $\delta^{13} \mathrm{CH}_{4}$ record during the YD-PB, rather than a ${ }^{13} \mathrm{C}$-enrichment. However, the next younger EDML datum is clearly younger than our maximum $\delta^{13} \mathrm{CH}_{4}$ suggesting that the enrichment trend is simply not resolved in EDML. Yet, even a plateau would still mark a disruption of the long-term ${ }^{13} \mathrm{C}$-depletion trend that initiates at the start of the deglaciation (Fischer et al., 2008), indicating different source/isotope dynamics during the $\left[\mathrm{CH}_{4}\right]$ rise than during the YD.

We conclude that a trend to higher $\delta^{13} \mathrm{CH}_{4}$ during the $\left[\mathrm{CH}_{4}\right]$ increase of the YD-PB is a statistically significant feature measured using three different extraction and analytical techniques. The feature is also possibly evident in ice from a different location and measured with an independent set-up. Thus, while our record has higher uncertainty given the necessity of applying a contaminated sample filter, it appears that the observed ${ }^{13} \mathrm{C}$-enrichment trend is robust enough to allow further interpretation.

\subsection{Triple isotope mass balance}

From the weighted linear regression, the atmospheric $\delta^{13} \mathrm{CH}_{4}$ values at the start and end of the YD-PB are $-46.9 \%$ and $-45.4 \%$, respectively. The $\delta^{13} \mathrm{CH}_{4}$ value of the total methane source can be derived from the atmospheric $\delta^{13} \mathrm{CH}_{4}$ by applying a weighted aggregate isotopic fractionation of total sink processes $(\varepsilon=-6.72 \%$ o), and correction for isotopic disequilibrium (Tans, 1997; Lassey et al., 2000) (Table 1 and Sect. 2.2.3.). Epsilon is calculated from 
the fractional proportion of each sink (including the highly fractionating atomic chlorine in the marine boundary layer (MBL) sink) and its ratio of the rate coefficients, $\alpha$, for each isotope as $\varepsilon=10^{3}(\alpha-1)$ in units of per mille. Using the increase in atmospheric $\left[\mathrm{CH}_{4}\right]$ across the YD-PB (ca. $250 \mathrm{ppb}$; Brook et al., 2000), an isotope mass balance yields the stable carbon isotope ratio of the additional emissions $\left(\delta^{13} \mathrm{CH}_{4} \uparrow \mathrm{T}\right)$ to be $-49.2 \pm 1.3 \%$.

To further narrow the possible source(s) of the increased methane flux during the YD-PB transition, we can use the other isotopes of methane $\left(\delta \mathrm{D}-\mathrm{CH}_{4}\right.$ and $\left.{ }^{14} \mathrm{CH}_{4}\right)$.

The GISP2 stable hydrogen isotope $\left(\delta \mathrm{D}-\mathrm{CH}_{4}\right)$ record for the YD-PB (Sowers, 2006) shows no significant trend within the transition with a near constant approximate value of $-90 \%$, although there are relatively few measurements and thus higher uncertainty. The mean $\delta \mathrm{D}-\mathrm{CH}_{4}$ value of the additional emissions $\left(\delta \mathrm{D}-\mathrm{CH}_{4} \uparrow \mathrm{T}\right)$ is $-314 \pm 8 \%$, after correction for sink processes $(\varepsilon=-223.9 \%$ ) and isotopic disequilibrium (Table 1 and Sect. 2.2.3). No primary $\mathrm{CH}_{4}$ source has this combined $\delta^{13} \mathrm{CH}_{4}$ and $\delta \mathrm{D}-\mathrm{CH}_{4}$ signature (Fig. 7). Therefore, it is likely that the $\Delta Q_{\mathrm{T}}$ during the YD-PB cannot be attributed to variations of a single source and the observed $\Delta Q_{\mathrm{T}}$ likely results from increased flux of two (or more) sources.

The YD-PB ${ }^{14} \mathrm{CH}_{4}$ record provides a third constraint (Petrenko et al., 2009), although this record has high uncertainty due to a correction for in-situ ${ }^{14} \mathrm{C}$ production and because the necessarily large samples contain gas of ages beyond the actual transition (Fig. 2). The ${ }^{14} \mathrm{CH}_{4}$ record shows a fossil methane contribution in the later stages of the YDPB $\left({ }^{14} \mathrm{CH}_{4} \uparrow \mathrm{T}=-138 \%\right.$; range of 1.5 to $-276 \%$, all values are converted from original age-corrected $\Delta^{14} \mathrm{C}$ notation; Petrenko et al., 2009). The values from Petrenko et al. (2009) are from their two-end member scenario assuming a YD GEM contribution of $50 \mathrm{Tg} \mathrm{CH}_{4}$ per year, which is close to other estimates of YD GEM emissions (Whiticar and Schaefer, 2007; Melton, 2010). Additionally, the values used in the triple mass balance have already accounted for the estimated shift in ${ }^{14} \mathrm{CH}_{4}$ values due to declining atmospheric ${ }^{14} \mathrm{CO}_{2}$ following Petrenko et al. (2009).

Using the isotope records of the YD-PB, three separate mass balances can be formulated for the sources of $\Delta Q_{\mathrm{T}}$ :

$\delta^{13} \mathrm{C} \uparrow \mathrm{C} \cdot \Delta Q_{\mathrm{C}}=\delta^{13} \mathrm{C}_{1} \cdot \Delta Q_{1}+\delta^{13} \mathrm{C}_{2} \cdot \Delta Q_{2}+\delta^{13} \mathrm{C}_{3} \cdot \Delta Q_{3}$

$\delta \mathrm{D} \uparrow \mathrm{C} \cdot \Delta Q_{\mathrm{C}}=\delta \mathrm{D}_{1} \cdot \Delta Q_{1}+\delta \mathrm{D}_{2} \cdot \Delta Q_{2}+\delta \mathrm{D}_{3} \cdot \Delta Q_{3}$

$\Delta^{14} \mathrm{C} \uparrow \mathrm{C} \cdot \Delta Q_{\mathrm{C}}=\delta^{14} \mathrm{C}_{1} \cdot \Delta Q_{1}+\delta^{14} \mathrm{C}_{2} \cdot \Delta Q_{2}+\delta^{14} \mathrm{C}_{3} \cdot \Delta Q_{3}$

where $\Delta Q_{n}$ and $\delta\left({ }^{13} \mathrm{C}, \mathrm{D},{ }^{14} \mathrm{C}\right) \uparrow_{n}$ are the fractional mass flux change across the YD-PB and the field measurement-based characteristic isotope values $\left(\delta^{13} \mathrm{CH}_{4}, \delta \mathrm{D}-\mathrm{CH}_{4},{ }^{14} \mathrm{CH}_{4}\right)$ of the $n$-th source term, respectively (Table 2). $\Delta Q_{\mathrm{C}}$ is the calculated total fractional mass flux (set as 1$). \delta\left({ }^{13} \mathrm{C}, \mathrm{D},{ }^{14} \mathrm{C}\right) \uparrow_{\mathrm{C}}$ are the calculated cumulative isotope values of the mixed sources, which can be compared to those derived from the ice records $\left(\delta\left({ }^{13} \mathrm{C}, \mathrm{D},{ }^{14} \mathrm{C}\right) \uparrow \mathrm{T}\right)$. As we have three mass balances

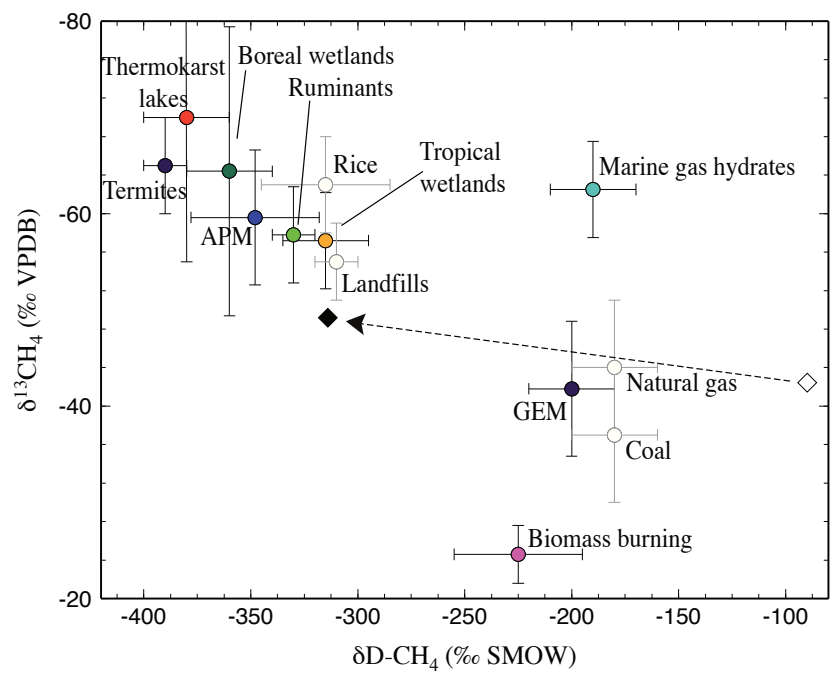

Fig. 7. Combination of characteristic $\delta^{13} \mathrm{CH}_{4}$ and $\delta \mathrm{D}-\mathrm{CH}_{4}$ signatures for the major primary sources of methane to the troposphere, together with the calculated mean source isotope values of the additional emissions ( $\delta^{13} \mathrm{CH}_{4} \uparrow \mathrm{T}, \delta \mathrm{D}-\mathrm{CH}_{4} \uparrow \mathrm{T}$ ) [black diamond] as derived from the ice core signal [white diamond] (Tables 1 and 2). Unfilled circles are anthropogenic sources.

with three unknowns, the mass balances can be solved simultaneously for $\Delta Q_{1}, \Delta Q_{2}$, and $\Delta Q_{3}$ (see Supplement $\mathrm{S} 1$ ). The results must account for the analytical uncertainties of the underlying isotope data. Therefore, error ranges have been conservatively selected for each of $\delta^{13} \mathrm{CH}_{4} \uparrow \mathrm{T}, \delta \mathrm{D}-$ $\mathrm{CH}_{4} \uparrow \mathrm{T}$, and ${ }^{14} \mathrm{CH}_{4} \uparrow \mathrm{T}$. The $\delta^{13} \mathrm{CH}_{4} \uparrow \mathrm{T}$ range $( \pm 1.3 \%$ o $)$ was determined from the standard error-weighted linear regression model's $99 \%$ confidence interval maximum range (Fig. 4). For $\delta \mathrm{D}-\mathrm{CH}_{4}$, as there is little or no trend across the YD-PB, the $\delta \mathrm{D}-\mathrm{CH}_{4} \uparrow \mathrm{T}$ range $( \pm 8 \%$ ) is taken as double the experimental external precision $( \pm 4 \%$ ) (Sowers, 2006) to accommodate any possible errors due to under-sampling. The available ${ }^{14} \mathrm{CH}_{4}$ record agrees well for the two YD measurements, while the two PB values differ substantially (Petrenko et al., 2009). The ${ }^{14} \mathrm{CH}_{4} \uparrow \mathrm{T}$ range is calculated from the mean $\mathrm{YD}^{14} \mathrm{CH}_{4}$ value and each of the $\mathrm{PB}^{14} \mathrm{CH}_{4}$ values as 1.5 to $-276 \%$. Given the ${ }^{14} \mathrm{CH}_{4}$ record's high uncertainty and low temporal resolution, we investigate the influence of this record on our results in Sect. 3.5.2.

As no primary $\mathrm{CH}_{4}$ source has the observed $\delta^{13} \mathrm{CH}_{4} \uparrow \mathrm{T}$ $\left(-49.2 \pm 1.3 \%\right.$ ) and $\delta \mathrm{D}-\mathrm{CH}_{4} \uparrow \mathrm{T}(-314 \pm 8 \%$ ) signature, matching calculated $\delta^{13} \mathrm{CH}_{4} \uparrow_{\mathrm{C}}$ values to the ice records requires a mix of ${ }^{13} \mathrm{C}$-enriched and ${ }^{13} \mathrm{C}$-depleted sources. Only biomass burning and geologic emissions of methane (GEM) have $\delta^{13} \mathrm{CH}_{4}$ that can serve as the ${ }^{13} \mathrm{C}$-enriched source. Six primary sources can supply sufficiently ${ }^{13} \mathrm{C}$ depleted methane: aerobic plant methane (APM), tropical and boreal wetlands, thermokarst lakes, ruminants, and termites. To satisfy the requirement for a fossil methane contribution, as shown by the ${ }^{14} \mathrm{CH}_{4}$ record, three sources emit 
Table 2. Characteristic isotope values for primary sources used in the triple mass balance calculations. Isotope values used in the standard scenario are denoted in bold font. Isotope $\delta^{13} \mathrm{CH}_{4}$ values that are assumed not to change with time are denoted by “-”. $\delta \mathrm{D}-\mathrm{CH}_{4}$ and $\Delta{ }^{14} \mathrm{CH}_{4}$ values are unchanged from modern isotope values. Alternative source values for the sensitivity tests are shown in parentheses.

\begin{tabular}{|c|c|c|c|c|c|}
\hline \multirow[t]{2}{*}{ Source } & \multicolumn{3}{|c|}{$\delta^{13} \mathrm{CH}_{4}(\% \circ$ vs. VPDB $)$} & \multirow{2}{*}{$\begin{array}{l}\delta \mathrm{D}-\mathrm{CH}_{4} \\
(\% \circ \text { vs. SMOW) }\end{array}$} & \multirow{2}{*}{$\begin{array}{l}\Delta^{14} \mathrm{CH}_{4} \\
\left(\% \text { vs. NBS OAS }{ }^{1}\right)\end{array}$} \\
\hline & Modern & $\mathrm{PB}^{2}$ & $\mathbf{Y D}^{2}$ & & \\
\hline Tropical wetlands & $\begin{array}{l}-58.9^{a} \\
\left(-60^{4}\right) \\
\left(-58^{5}\right)\end{array}$ & -57 & -57.2 & $\begin{array}{l}-315^{b} \\
\left(-320^{5}\right)\end{array}$ & $130^{f}$ \\
\hline Boreal wetlands & $\begin{array}{l}-64.5 \\
\left(-64^{5}\right) \\
(-60)^{6}\end{array}$ & -64.2 & -64.4 & $\begin{array}{l}-360^{b} \\
\left(-327^{5}\right)\end{array}$ & $130^{\mathrm{f}}$ \\
\hline Thermokarst lakes & $-70^{\mathrm{c}}$ & - & - & $-380^{\mathrm{c}}$ & $-738.5^{g}$ \\
\hline APM & $-61^{d}$ & -59.4 & -59.6 & $-348^{\mathrm{e}}$ & $200^{h}$ \\
\hline Biomass burning & $\begin{array}{l}-24.6^{a} \\
\left(-23^{5}\right) \\
\left(-25^{4}\right)\end{array}$ & -26 & -26.2 & $-225^{\mathrm{a}}$ & $300^{\mathrm{i}}$ \\
\hline Marine gas hydrates & $\begin{array}{l}-62.5^{\mathrm{a}} \\
\left(-60^{5}\right)\end{array}$ & - & - & $-190^{\mathrm{a}}$ & $-1000^{j}$ \\
\hline Ruminants & $\begin{array}{l}-60.5^{a} \\
\left(-59^{5}\right) \\
\left(-62^{4}\right)\end{array}$ & -57.6 & -57.8 & $\begin{array}{l}-\mathbf{3 3 0}^{\mathrm{a}} \\
\left(-300^{5}\right)\end{array}$ & $200^{f}$ \\
\hline GEM & $\begin{array}{l}-41.8^{a} \\
\left(-40^{4}\right)\end{array}$ & - & - & $-200^{\mathrm{a}}$ & $-1000^{\mathrm{k}}$ \\
\hline Termites & $\begin{array}{l}-65^{\mathrm{a}} \\
\left(-57^{4}\right)\end{array}$ & -64.8 & -65 & $-390^{\mathrm{a}}$ & $\mathbf{2 3 8}^{1}$ \\
\hline
\end{tabular}

${ }^{1}$ NBS OAS: oxalic acid standard (Donahue et al., 1990)

2 Modern values are adapted for the PB and YD as in Schaefer and Whiticar (2008) and Whiticar and Schaefer (2007). If the initial modern value chosen differs from those in Schaefer and Whiticar (2008), the absolute change between time periods is applied to the isotope value chosen. Source isotope values that are not expected to be sensitive to environmental and climatic changes are kept at their modern isotope values. Equivalent changes due to the palaeoenvironment have not been quantified for $\delta \mathrm{D}-\mathrm{CH}_{4}$. Thus, modern values are used throughout (with the exception of the tropical wetlands sensitivity test outlined in Sect. 3.5.1). $\Delta{ }^{14} \mathrm{CH}_{4}$ values are assumed to not systematically change across the time periods.

3 Table 1 of Etiope et al. (2008) lists the range of values for the different geologic sources.

${ }^{4} \delta^{13} \mathrm{CH}_{4}$ values from Lassey et al. (2007).

$5 \delta^{13} \mathrm{CH}_{4}$ and $\delta \mathrm{D}-\mathrm{CH}_{4}$ values from Fischer et al. (2008).

6 To test the suggestion of MacDonald et al. (2006) that boreal wetlands during the deglaciation would be likely characterized by minerotrophic fens (e.g. $-60 \%$ o but ranging -50 to $-73 \%$; (Bellisario et al., 1999) rather than the present Sphagnum bog complexes.

a Whiticar and Schaefer (2007)

b Based upon Nakagawa et al. (2002a,b) and Waldron et al. (1999)

c Walter et al. (2008)

d Value is an average based on Keppler et al. (2006) and Vigano et al. (2009) for detached plant material. Whole plant values are not used due to the non-biotic nature of the $\mathrm{CH}_{4}$ production (Nisbet et al., 2009). A weighted average between $\mathrm{C}_{3}$ and $\mathrm{C}_{4}$ plants was based upon $25 \%$ global grassland coverage, $57 \%$ of which are $\mathrm{C}_{4}$ plants (Collatz et al., 1998).

e The measurements of Vigano et al. (2009) are the only reported $\delta \mathrm{D}-\mathrm{CH}_{4}$ values. Isotope value is a weighted average of $\mathrm{C}_{3}$ and $\mathrm{C}_{4}$ plants in same proportion as noted above.

${ }^{f}$ Lassey et al. (2007)

$\mathrm{g}$ Walter et al. (2008). Estimate has high uncertainty as it is based on data from only two thermokarst lakes. Thermokarst lakes have been shown to emit methane with $\Delta^{14} \mathrm{CH}_{4}$ values ranging from modern to $-993 \%$. Thus, we follow Petrenko et al. (2009) in assuming the ${ }^{14} \mathrm{C}$ in thermokarst lakes is a mixing of two-end member organic substrate materials: one modern and the other ${ }^{14} \mathrm{C}$-free. We assume the fraction of these two end-members is the same during the YD and PB as present and use the same flux-weighted average (Walter et al., 2008; Petrenko et al., 2009).

${ }^{\mathrm{h}}$ We are not aware of any measured APM ${ }^{14} \mathrm{CH}_{4}$ values. Therefore, we assign APM the ${ }^{14} \mathrm{C}$ value of ruminant $\mathrm{CH}_{4}$.

${ }^{\mathrm{i}}$ Quay et al. (1999). We assume that natural biomass burning has the same $\Delta^{14} \mathrm{CH}_{4}$ values as anthropogenic biomass burning measured $\Delta^{14} \mathrm{CH}_{4}$ values.

j Winckler et al. (2002)

${ }^{\mathrm{k}}$ Quay et al. (1999). We assume mined natural gas has the same $\Delta^{14} \mathrm{CH}_{4}$ value as GEM

${ }^{1}$ Wahlen et al. (1989b) 
Table 3. Triple isotope mass balance model results for YD-PB source scenarios. Fractional source contributions are calculated simultaneously via the triple isotope mass balance and compared to the mean ice record $\delta^{13} \mathrm{CH}_{4} \uparrow_{\mathrm{T}}, \delta \mathrm{D}-\mathrm{CH}_{4} \uparrow_{\mathrm{T}}$ and ${ }^{14} \mathrm{CH}_{4} \uparrow_{\mathrm{T}}$ values for scenario acceptance. All valid scenarios (bold font) pass the acceptance criteria outlined in the text. Solutions with negative emissions are physically meaningless and are listed in Table S4 in the Supplement.

\begin{tabular}{|c|c|c|c|c|c|c|c|c|c|c|c|}
\hline \multirow[b]{2}{*}{$\begin{array}{l}\text { Scenario } \\
\#\end{array}$} & \multicolumn{11}{|c|}{ Source Fractional Contribution $(\Delta Q)$} \\
\hline & $\begin{array}{l}\text { Biomass } \\
\text { burning }\end{array}$ & GEM & $\begin{array}{c}\text { Thermokarst } \\
\text { lakes }\end{array}$ & $\begin{array}{l}\text { Biogenic } \\
\text { marine } \\
\text { gas } \\
\text { hydrates }\end{array}$ & $\begin{array}{c}\text { Aerobic } \\
\text { plant } \\
\text { methane }\end{array}$ & Ruminants & $\begin{array}{l}\text { Tropical } \\
\text { wetlands }\end{array}$ & $\begin{array}{c}\text { Boreal } \\
\text { wetlands }\end{array}$ & Termites & $\Delta Q_{\mathrm{C}}$ & $\begin{array}{c}\text { Satisfy } \\
\text { acceptance } \\
\text { criteria? }\end{array}$ \\
\hline 1 & 0.54 & & 0.43 & & 0.08 & & & & & 1.05 & $\mathbf{Y}$ \\
\hline 2 & 0.55 & & 0.43 & & & 0.08 & & & & 1.06 & $\mathbf{Y}$ \\
\hline 3 & 0.56 & & 0.43 & & & & 0.08 & & & 1.07 & $\mathbf{Y}$ \\
\hline 4 & 0.56 & & 0.43 & & & & & 0.07 & & 1.06 & $\mathbf{Y}$ \\
\hline 5 & 0.53 & & 0.43 & & & & & & 0.08 & 1.04 & $\mathbf{Y}$ \\
\hline 6 & 0.60 & 0.38 & & & 0.29 & & & & & 1.28 & $\mathrm{~N}$ \\
\hline 7 & 0.64 & 0.39 & & & & 0.28 & & & & 1.31 & $\mathrm{~N}$ \\
\hline 8 & 0.68 & 0.38 & & & & & 0.28 & & & 1.33 & $\mathrm{~N}$ \\
\hline 9 & 0.65 & 0.37 & & & & & & 0.26 & & 1.28 & $\mathrm{~N}$ \\
\hline 10 & 0.56 & 0.37 & & & & & & & 0.29 & 1.22 & $\mathrm{~N}$ \\
\hline 11 & 0.71 & & 0.37 & 0.08 & & & & & & 1.15 & $\mathrm{~N}$ \\
\hline 12 & 1.01 & 0.24 & & 0.20 & & & & & & 1.45 & $\mathrm{~N}$ \\
\hline
\end{tabular}

fossil or ${ }^{14} \mathrm{C}$-depleted methane: GEM, thermokarst lakes, and marine gas hydrates. There are then 29 possible threesource scenarios that include a ${ }^{13} \mathrm{C}$-enriched, a ${ }^{13} \mathrm{C}$-depleted and a fossil component, where the contribution from each source can be quantified from the triple mass balance (Table S4 in the Supplement). We impose two criteria on the mass balance calculation's source combinations to identify valid scenarios. First, the calculated cumulative isotope values, $\delta\left({ }^{13} \mathrm{C}, \mathrm{D},{ }^{14} \mathrm{C}\right) \uparrow \mathrm{C}$, must reproduce the ice isotope records, i.e. $\delta\left({ }^{13} \mathrm{C}, \mathrm{D},{ }^{14} \mathrm{C}\right) \uparrow \mathrm{C}$ must equal $\delta\left({ }^{13} \mathrm{C}, \mathrm{D},{ }^{14} \mathrm{C}\right) \uparrow \mathrm{T} . \mathrm{Sec}-$ ond, the fractional contribution from each source, $\Delta Q_{1}$, $\Delta Q_{2}$, and $\Delta Q_{3}$, must sum to $1.0 \pm 0.1$ (the closer to one, the more probable). The value of this second constraint is chosen arbitrarily. Obviously several simplifications and assumptions are intrinsic to the triple mass balance approach including constant and representative source isotope values through the transition, constant sink isotopic fractionation (the sink strength can vary; it just changes the magnitude of the $\mathrm{CH}_{4}$ increase), and the assumption that the $\mathrm{CH}_{4}$ increase can be represented adequately by the contribution of three or less sources. Representative source isotope values could also have changed from modern values and are investigated in Sect. 3.4.

All valid scenarios derived from the triple isotope mass balances listed in Table 3 have in common that the increased $\mathrm{CH}_{4}$ flux across the YD-PB, $\Delta Q_{\mathrm{T}}$, is predominantly sourced $(>50 \%)$ from biomass burning with a strong contribution $(\sim 43 \%)$ from thermokarst lakes. The remaining sources (global wetlands, APM, termites, and ruminants) appear equally likely to have contributed a minor amount $(>10 \%)$. A previous ice core $\delta^{13} \mathrm{CH}_{4}$ study concluded that the biomass burning source flux remained stable between the
YD and PB periods (Fischer et al., 2008). Their conclusion is based on the comparison of average YD and $\mathrm{PB}$ values using the long-term decreasing $\delta^{13} \mathrm{CH}_{4}$ trend. In contrast, the pronounced rise in pyrogenic $\mathrm{CH}_{4}$ reported here specifically applies to the short transition period while $\left[\mathrm{CH}_{4}\right]$ and $\delta{ }^{13} \mathrm{CH}_{4}$ change. The arbitrarily chosen selection criteria for valid scenarios $\left(\Delta Q_{1}, \Delta Q_{2}\right.$, and $\Delta Q_{3}$ must sum to $1.0 \pm 0.1$, or $\pm 10 \%$ ) appear to be reasonably chosen as the criteria would have to raised to $15 \%$ to allow another possible scenario (one that includes thermokarst lakes, biomass burning, and marine gas hydrates). To bring in another source scenario that would challenge the dominant sources from the other valid scenarios would necessitate raising the inclusion limit to $22 \%$ (for a scenario including biomass burning, GEM, and termites). By contrast, of the 29 possible source combinations, the five that pass the acceptance criteria all have a summed fractional contribution that falls within 4 to $7 \%$ of unity.

Accounting for the uncertainties in the various isotope data from the ice records by investigating the minimum and maximum values of each isotope while holding the other two at their mean values (Table S5 in the Supplement) produces ranges for the various sources as $\sim 42-66 \%$ for biomass burning, $\sim 27-59 \%$ for thermokarst lakes and $\sim 0-29 \%$ for the complementing third source. Given these probability ranges, the finding that $\Delta Q_{\mathrm{T}}$ is composed mainly from biomass burning and thermokarst lakes with some contribution from a third source (or several minor ones) seems robust. However, additional uncertainty is introduced by incomplete understanding of present and past methane isotope budgets, which are investigated in the following section's sensitivity tests. 
From Table S5 in the Supplement, three scenarios deserve further comment. If the YD-PB methane isotope values are best represented by the minimum $\delta \mathrm{D}-\mathrm{CH}_{4} \uparrow T$ value $(-322 \%)$ or the maximum $\delta^{13} \mathrm{CH}_{4} \uparrow T$ value $(-47.9 \%$ ), then the triple mass balance calculates a two-source mix of biomass burning and thermokarst lakes. While these source scenarios exceed the $\sum \Delta Q$ acceptance criteria (by 1 to $2 \%$ ), they fit the atmospheric isotope constraints better than any other source combinations for the minimum $\delta \mathrm{D}-\mathrm{CH}_{4} \uparrow T$ or maximum $\delta^{13} \mathrm{CH}_{4} \uparrow T$ values (including all other source combinations listed in Table S6 in the Supplement). Also the minimum ${ }^{14} \mathrm{CH}_{4} \uparrow T$ value $(-276 \%$ ) produces no valid scenarios. This implies that a fossil contribution over the YD-PB transition of this magnitude is unlikely. The source fractional contributions thus do not include this scenario in the calculation of their ranges.

\subsection{Mass balance sensitivity tests}

The source contributions quoted in Sect. 3.3 are based on a standard scenario that uses modern isotope values adapted for the Younger Dryas conditions (Schaefer and Whiticar, 2008) (Tables 1 and 2). We varied these parameters to investigate the sensitivity of the triple mass balance results for (i) alternative source isotope values, proportional sink strengths, and sink fractionation factors; (ii) the impact of changing environmental and climatic conditions upon source isotope values, including changes in the distributions of, and methane produced by, $\mathrm{C}_{3}$ and $\mathrm{C}_{4}$ vegetation (Schaefer and Whiticar, 2008); and (iii) different strengths of the MBL atomic chlorine sink. All sensitivity tests using the mean ice core based $\delta^{13} \mathrm{CH}_{4} \uparrow T, \delta \mathrm{D}-\mathrm{CH}_{4} \uparrow T$, and ${ }^{14} \mathrm{CH}_{4} \uparrow T$ values are described in detail below. The sensitivity tests produce different sets of source scenarios that are subjected to the same evaluation criteria as the standard scenario. Valid scenarios are shown in Table S6 in the Supplement.

\subsubsection{Fen-dominated wetlands}

At the YD-PB, boreal peatlands were in their early development stages, which are likely best characterized as fendominated wetlands (MacDonald et al., 2006), rather than ombrotrophic Sphagnum-dominated bogs that are extensive in the boreal region today with a $\delta^{13} \mathrm{CH}_{4}$ value of about $-65 \%$, as used in the standard scenario. Fen-dominated wetlands are arguably better represented by a more ${ }^{13} \mathrm{C}$ enriched $\delta^{13} \mathrm{CH}_{4}$ value of $-60 \%$ (MacDonald et al., 2006) (Table 2). We investigated the triple mass balance sensitivity to this selection of the $\delta^{13} \mathrm{CH}_{4}$ value and found the changes to be minor. None of the scenarios changed their status as valid or invalid (therefore not included in Table S6 in the Supplement). The maximum estimated fractional contribution from boreal wetlands increases from 0.07 to 0.10 .

\subsubsection{Changing environmental and climatic conditions}

In our standard scenario, source isotope values are changed from present-day literature values following Schaefer and Whiticar (2008) and Whiticar and Schaefer (2007) to reflect different environmental and climatic conditions during the YD period. For $\delta^{13} \mathrm{CH}_{4}$, we account for changes between modern and Preboreal/YD environmental and climatic conditions including (i) changes in atmospheric $\delta^{13} \mathrm{CO}_{2}$; (ii) vegetation patterns, including $\mathrm{C}_{3} / \mathrm{C}_{4}$ plant distribution patterns, which influence the $\delta^{13} \mathrm{C}$ of the organic $\mathrm{CH}_{4}$ precursor material; (iii) the impact of temperature change on $\mathrm{CH}_{4}$ production itself, particularly in wetlands; and (iv) partial oxidation before emission to the atmosphere. To test the triple mass balance model sensitivity to these changes, we investigated two scenarios using $\delta^{13} \mathrm{CH}_{4}$ values characteristic of (i) modern conditions and (ii) the Preboreal period (Table 2). All other model parameters are unchanged. The results from these two tests are shown as "Modern Scenario" and "Preboreal Scenario" in Table S6 in the Supplement with no significant changes to the results of the standard scenario.

\subsubsection{Atomic chlorine in the marine boundary layer sink}

A recent modelling study suggests that $\delta^{13} \mathrm{CH}_{4}$-enrichment on the order of $0.3 \%$ can result from glacial to interglacial changes in the sink configuration, primarily due to changes in the highly fractionating MBL atomic chlorine sink (Levine et al., 2011). As our observed trend far exceeds the modelled value, this supports the view that that the processes are primarily source driven, although a contribution from sink changes cannot be ruled out. The impact of the inferred atomic chlorine sink in the MBL (Allan et al., 2001) is thus investigated. The strength of the MBL sink is based upon the estimated modern strengths from Allan et al. (2007). The standard scenario assumes a MBL sink at the estimated minimum modern strength (Allan et al., 2007) (Table 1). Sensitivity tests explore the influence of assuming (i) no MBL sink, (ii) the mean, and (iii) the maximum MBL sink strength from Allan et al. (2007) (Scenarios "No MBL Sink", "Mean MBL Sink", "Max MBL Sink" in Table S6 in the Supplement). All other model parameters remain the same as the standard scenario, except the fractional contributions from the other sinks are adjusted to accommodate the changes in the MBL sink. The ranges used in the sensitivity tests are -5.39 to $-9.02 \%$ for total $\varepsilon_{\mathrm{C}}$ and -218.3 to $-233.6 \%$ for total $\varepsilon_{\mathrm{D}}$. The results of these changes to the MBL sink are small (Table S6 in the Supplement). The most significant difference is that a scenario with biomass burning (contribution of $66 \%$ ), thermokarst lakes $(40 \%)$ and marine gas hydrates $(4 \%)$ is valid for a zero MBL sink; however, this scenario is on the limit of the acceptance criteria. We note that these tests, as well as all mass balance scenarios, assume that $\varepsilon$-values do not change through the transition. 


\subsubsection{Alternative $\delta^{13} \mathrm{CH}_{4}$ and $\delta \mathrm{D}-\mathrm{CH}_{4}$ characteristic budgets}

Alternative characteristic primary isotope value estimates for methane source types are used in the literature. Here we test model sensitivity of alternative source budgets compared to our chosen primary $\delta^{13} \mathrm{CH}_{4}$ and $\delta \mathrm{D}-\mathrm{CH}_{4}$ values (Tables 1 and 2). The first alternative budget tested is that of Fischer et al. (2008). This budget does not include termites, GEM, thermokarst lakes or an MBL sink. Additionally, their APM characteristic isotope values are not supported by measurements (Keppler et al., 2006; Vigano et al., 2009). We thus do not investigate scenarios involving these sources/sink with the exception of thermokarst lakes where our standard value is used.

The second alternative budget is that of Lassey et al. (2007), which does not include source characteristic values for APM, marine gas hydrates, or thermokarst lakes. Additionally, they do not distinguish $\delta^{13} \mathrm{CH}_{4}$ values between tropical and boreal wetlands (Lassey et al., 2007). We do not investigate scenarios involving APM or marine gas hydrates with the Lassey et al. (2007) budget.

While both Lassey et al. (2007) and Fischer et al. (2008) address different time scales than ours and thus have no direct bearing on our conclusions, they demonstrate the sensitivity of the triple mass balance results to different representative source isotope values. The mass balance results of the two alternative budgets by Fischer et al. (2008) and Lassey et al. (2007) (likewise named in Table S6 in the Supplement) do not produce additional valid scenarios compared to the standard scenario. This further supports the conclusion that the additional YD-PB $\mathrm{CH}_{4}$ emissions were predominantly caused by biomass burning and thermokarst lakes with only small contributions from other sources.

From the sensitivity tests, the mass balances are most sensitive to changes in the primary source isotope values (Table S6 in the Supplement). However, these probable alternative isotope values result in valid scenarios with the same dominant sources as the standard scenario. While these sensitivity tests explore a relatively wide range in source characteristic isotope values (and even more so in Sect. 3.5.1.), it could be possible for the characteristic isotope values to change through the course of the transition in response to environmental conditions, or some unknown processes, to values outside of the range of our tests. Given that the processes by which this could occur remain unknown, we are not able to accurately test for this possibility, but we do wish to acknowledge it and the associated uncertainty it brings.

\subsection{Dominant source contributions}

The fractional source flux changes from the triple mass balance calculations can be converted to absolute fluxes (in units of $\mathrm{Tg} \mathrm{CH}_{4} \mathrm{yr}^{-1}$ ) by assuming a total flux increase $\Delta Q_{\mathrm{T}}$ of $64 \mathrm{Tg} \mathrm{CH}_{4} \mathrm{yr}^{-1}$ (Petrenko et al., 2009). Due to the uncertainties in the ice core data and the model assumptions, the derived absolute fluxes for individual sources should be regarded as a best estimate only. However, the exercise may be informative to assess if individual source changes are probable in light of total source strengths and their estimated variability.

We calculate $\Delta Q$ for biomass burning to be $27-$ $42 \mathrm{Tg} \mathrm{yr}^{-1}$. This indicates an increase of up to $\sim 100 \%$ by the end of the YD-PB, compared to estimates of the YD biomass burning $\mathrm{CH}_{4}$ flux (Fischer et al., 2008; Melton, 2010). For comparison, global methane budget modelling results covering the last two decades show modern pyrogenic emissions reaching almost $30 \mathrm{Tg} \mathrm{yr}^{-1}$ interannually (Bousquet et al., 2006; Drevet, 2008). While these studies necessarily include anthropogenic influences, they still illustrate the recognized sensitivity of biomass burning to climate and vegetation (Westerling et al., 2006; Bowman et al., 2009) even in the absence of an event the scale of the YD-PB. Changes in fire regimes can be related to fuel accumulation and vegetation distribution, as well as ignition sources, e.g. lightning (Westerling, 2009). Evidence of enhanced burning close to the YD-PB is observed in global charcoal datasets (Power et al., 2008; Daniau et al., 2010) and a North American charcoal and pollen dataset (Marlon et al., 2009).

It is also worthwhile to investigate if $\mathrm{CH}_{4}$ isotopes can provide quantitative estimates of changes in global biomass burning. Carbon monoxide is a trace gas component that can be used to confirm estimates of biomass burning. $\mathrm{CO}$ is largely produced through biomass burning and oxidation of non-methane hydrocarbons, and the relative proportions of these sources can be distinguished using stable isotopes. Recent results from an Antarctic ice core record CO mixing ratio and isotopic ratios record spanning the last $650 \mathrm{yr}$ (Wang et al., 2010) support the biomass burning estimates from two Antarctic ice core $\left[\mathrm{CH}_{4}\right]$ and $\delta^{13} \mathrm{CH}_{4}$ records (Ferretti et al., 2005; Mischler et al., 2009) and are generally consistent with the tropical charcoal index (Daniau et al., 2010). The Wang et al. (2010) study thus supports the ability of $\delta^{13} \mathrm{CH}_{4}$ to estimate changes in global biomass burning fluxes.

We estimate thermokarst lake $\Delta Q$ to be $17-38 \mathrm{Tg} \mathrm{yr}^{-1}$, i.e. slightly higher than derived from thermokarst lake basal initiation dates $\left(\sim 10-16 \mathrm{Tg} \mathrm{yr}^{-1}\right)$ (Walter et al., 2007). As well, a recent reanalysis of the thermokarst lakes basal initiation dataset using a different methodology finds that the main thermokarst lakes expansion occurred after the YD-PB (Reyes and Cooke, 2011), contrary to our results. We note that both of these studies using thermokarst lake basal ${ }^{14} \mathrm{C}$ initiation dates are somewhat uncertain as the database contains only 66 dates. As well, the initiation dates do not necessarily capture lateral expansion caused by climate changes (similar to peatlands; Korhola et al., 2010), which may at least partially account for the discrepancy between our estimates and those based upon thermokarst basal initiation dates. Thermokarst lake emissions into the Northern Hemisphere are consistent with the increase in inter-hemispheric 
$\left[\mathrm{CH}_{4}\right]$ gradient between the averages of the YD and PB periods (Brook et al., 2000; Dällenbach et al., 2000), although the latter may not be indicative of the short-term transition dynamics. In conclusion, there is no clear support for our estimated magnitude of increased thermokarst lake $\mathrm{CH}_{4}$ production during the YD-PB from field evidence indicating a possible overestimate.

Reyes and Cooke (2011) also reanalyzed two large basal peatland ${ }^{14} \mathrm{C}$ datasets: one for Alaska (Jones and Yu, 2010) and the other spanning all circumpolar regions (MacDonald et al., 2006). They conclude that northern peatlands could not have been the primary drivers of the rapid increases in $\left[\mathrm{CH}_{4}\right]$ observed during the deglaciation. Their analysis is consistent with our triple mass balance results that show a minimal contribution from boreal peatlands, even if we assume the newly formed peatlands to be more productive minerotrophic fens rather than the present-day ombrotrophic Sphagnum-dominated bogs (MacDonald et al., 2006) (Table 2, Sect. 3.4.1). Both their and our studies do not support an earlier suggestion (Jones and Yu, 2010) that Alaskan peatlands, less encumbered by ice sheet dynamics and thermal inertia than other circumpolar peatlands, could have contributed strongly to the $\mathrm{CH}_{4}$ rise.

Scenarios with substantial contributions ( $>10 \%)$ from either GEM (including thermogenic clathrates) or biogenic marine clathrates overestimate $\Delta Q_{\mathrm{T}}$ by at least $22 \%$ and $45 \%$, respectively (Table 3 ) and do not satisfy the isotope constraints. Thus, our findings are not consistent with any significant clathrate release over hydrocarbon seeps (GEM) (Hill et al., 2006) during the YD-PB.

\subsubsection{Tropical wetlands}

Tropical wetlands have been discussed as the predominant driver of the atmospheric methane concentration increase over the YD-PB (Brook et al., 2000). These arguments are based on the size of this source at present day (Denman et al., 2007) and inferred changes to the low-latitude hydrologic cycle (Peterson et al., 2000). However, from the triple mass balance results (Tables 3 and Table S4 in the Supplement), tropical wetlands do not appear likely to have greatly increased their $\mathrm{CH}_{4}$ flux over the YD-PB, while we note that stable isotope values of wetland sources are possibly sensitive to changes in the ratio of net to gross $\mathrm{CH}_{4}$ production (Sowers, 2006) and source water $\delta \mathrm{D}-\mathrm{H}_{2} \mathrm{O}$ values (Bock et al., 2010).

The hydrogen isotope ratio of wetland methane is ultimately derived from the hydrogen isotope ratio of meteoric water and hence precipitation (Whiticar, 1993) (recirculation notwithstanding). The hydrogen isotope ratio of precipitation is not constant through time. It is influenced by several factors, including the isotopic composition of the ocean, which, in turn, is largely determined by the size of terrestrial ice sheets. For example, the $\delta \mathrm{D}-\mathrm{H}_{2} \mathrm{O}$ values of the ocean during the Last Glacial Maximum ( $\sim 21 \mathrm{kyr}$ BP, LGM) are reported to be 6.5 to $9 \%$ more ${ }^{2} \mathrm{H}$-enriched than at present (Schrag et al., 2002). In addition, the modulating Rayleigh distillation effect will be strengthened by a stronger pole-toequator temperature gradient in cold climates. Modelling of the LGM suggests that $\delta \mathrm{D}-\mathrm{H}_{2} \mathrm{O}$ values were 15 to $30 \%$ more ${ }^{2} \mathrm{H}$-depleted in northern latitudes, while values in low latitudes may have been 0 to $8 \%$ more ${ }^{2} \mathrm{H}$-enriched than at present (Jouzel et al., 2000). The rapid changes in the hydrologic cycle proxies are suggested to reflect movement of the Intertropical Convergence Zone (ITCZ). Close to the ITCZ, the changes are unlikely to have a major effect on the $\delta \mathrm{D}$ $\mathrm{H}_{2} \mathrm{O}$ as the water is rapidly recycled; however, the changes should lead to a latitudinal relocation of tropical wetlands. This effect has been assumed to be relatively small (Bock et al., 2010). For the carbon system, the $\delta^{13} \mathrm{CH}_{4}$ changes due to environmental and climate changes of the YD have been estimated to be $1.7 \%$ (Schaefer and Whiticar, 2008). No similar estimate exists for the hydrogen system.

To test the mass balance results for tropical wetlands, the $\delta \mathrm{D}-\mathrm{CH}_{4}$ and $\delta^{13} \mathrm{CH}_{4}$ characteristic values for tropical wetlands were changed to extreme values to test the maximum contribution from tropical wetlands. The tropical wetland $\delta \mathrm{D}-\mathrm{CH}_{4}$ value was changed to range between $-300 \%$ and $-330 \%$ (from a standard value of $-315 \%$ o). Shifts of this magnitude are larger than present evidence indicates (Jouzel et al., 2000; Bock et al., 2010) and result in a maximum estimate of tropical wetland $\mathrm{CH}_{4}$ flux increase. The tropical wetland $\delta^{13} \mathrm{CH}_{4}$ value is changed by $+8.9 \%$ from the modern value, or $+7.2 \%$ from the estimated YD value, to $-50 \%$ (see Table 1 for standard values) in the direction of the mean $\delta^{13} \mathrm{CH}_{4} \uparrow T$ value. To achieve a $\delta^{13} \mathrm{CH}_{4}$ value this ${ }^{13} \mathrm{C}$-enriched would require a disproportionately large contribution from $\mathrm{C}_{4}$ organic matter to tropical wetland emissions as compared to estimated $\mathrm{C}_{4} / \mathrm{C}_{3}$ distributions (Collatz et al., 1998; Schaefer and Whiticar, 2008). However, even with these extreme characteristic values, the fractional contribution only increases from 0.08 (standard scenario with mean $\delta^{13} \mathrm{CH}_{4} \uparrow T, \delta \mathrm{D}-\mathrm{CH}_{4} \uparrow T$, and ${ }^{14} \mathrm{CH}_{4} \uparrow T$ values) to 0.22 . As well, no additional scenarios pass the acceptance criteria besides those including biomass burning and thermokarst lakes as the main sources, as is the case for the standard tropical wetlands isotope values. Therefore, within the tested uncertainty ranges, our isotope mass balance results are not consistent with the hypothesis that tropical wetlands were the major source of increased methane flux during the YD-PB transition.

\subsubsection{Test of the influence of the ${ }^{14} \mathrm{CH}_{4}$ dataset}

Our triple mass balance uses the ${ }^{14} \mathrm{CH}_{4}$ dataset of Petrenko et al. (2009) as it is the only ${ }^{14} \mathrm{CH}_{4}$ dataset presently available. This dataset is not ideal given the necessarily low temporal resolution of the samples and high uncertainty due to corrections for cosmogenic ${ }^{14} \mathrm{C}$ production. To test the sensitivity of the results based on the triple mass balance to the 
Table 4. $\delta^{13} \mathrm{CH}_{4}$ and $\delta \mathrm{D}-\mathrm{CH}_{4}$ mass balance results for scenarios with biomass burning and geologic emissions of methane as the ${ }^{13} \mathrm{C}$ enriched contributing source. Results are presented as percent mismatch between the fractional source contributions calculated independently by the $\delta^{13} \mathrm{CH}_{4}$ and the $\delta \mathrm{D}-\mathrm{CH}_{4}$ mass balances (methodology is further described in Sect. 3.5.2.). The characteristic source and sink isotope values and source fractional strengths are for the standard scenario as in the triple mass balance (see Tables 1 and 2). The mean percent mismatch is calculated using mean $\delta^{13} \mathrm{CH}_{4} \uparrow_{\mathrm{T}}\left(-49.2 \%\right.$ o ) and $\delta \mathrm{D}-\mathrm{CH}_{4} \uparrow_{\mathrm{T}}(-314 \%$ o ) values. Also presented are the minimums and maximums in percent mismatches between the mass balances for the range of $\delta^{13} \mathrm{CH}_{4} \uparrow \mathrm{T}\left(1.3 \%\right.$ ) and $\delta \mathrm{D}-\mathrm{CH}_{4} \uparrow \mathrm{T}(8 \%$ ) values (see Sect. 3.3). From this uncertainty range, the upper limit in percent mismatch values is consistently given by the constraint of a $\delta \mathrm{D}-\mathrm{CH}_{4} \uparrow \mathrm{T}$ value of $-322 \%$ and $\delta^{13} \mathrm{CH}_{4} \uparrow \mathrm{T}$ value of $-47.9 \%$. The lower limit is consistently given by the constraints of a $\delta \mathrm{D}-\mathrm{CH}_{4} \uparrow \mathrm{T}$ value of $-306 \%$ and $\mathrm{a} \delta{ }^{13} \mathrm{CH}_{4} \uparrow \mathrm{T}$ value of $-50.4 \%$. All percent mismatch values less than $10 \%$ (similar to the criteria for an acceptable scenario in the triple mass balance; see Sec. 3.3) are considered valid scenarios and are highlighted in bold font.

\begin{tabular}{|c|c|c|c|c|c|c|c|}
\hline \multirow{2}{*}{$\begin{array}{l}\text { Source of }{ }^{13} \mathrm{C} \text {-enriched } \mathrm{CH}_{4} \\
\text { Biomass } \\
\text { burning }\end{array}$} & \multicolumn{7}{|c|}{ Source of ${ }^{13} \mathrm{C}$-depleted $\mathrm{CH}_{4}$} \\
\hline & APM & Ruminants & $\begin{array}{l}\text { Tropical } \\
\text { wetlands }\end{array}$ & $\begin{array}{r}\text { Boreal } \\
\text { wetlands }\end{array}$ & $\begin{array}{r}\text { Thermokarst } \\
\text { lakes }\end{array}$ & Termites & $\begin{array}{r}\text { Biogenic } \\
\text { marine } \\
\text { gas } \\
\text { hydrates }\end{array}$ \\
\hline Upper limit & -13.8 & -23.6 & -37.6 & -14.9 & -12.9 & -2.8 & 336.7 \\
\hline Mean & -3.5 & -12.0 & -24.7 & -5.7 & -4.9 & 5.3 & 317.3 \\
\hline Lower limit & 6.8 & -0.3 & -11.7 & 3.5 & 3.2 & 13.5 & 298.0 \\
\hline \multicolumn{8}{|l|}{ GEM } \\
\hline Upper limit & -48.0 & -55.5 & -66.3 & -49.1 & -46.0 & -37.8 & 1248.7 \\
\hline Mean & -35.6 & -41.6 & -51.2 & -38.6 & -37.2 & -28.2 & 1174.7 \\
\hline Lower limit & -23.0 & -27.4 & -36.0 & -27.9 & -28.2 & -18.5 & 1100.9 \\
\hline
\end{tabular}

use of the ${ }^{14} \mathrm{CH}_{4}$ dataset, we have performed a mass balance analysis using only the $\delta^{13} \mathrm{CH}_{4}$ and $\delta \mathrm{D}-\mathrm{CH}_{4}$ datasets. This approach, of course, allows only a two-source mixture, which should be reasonable given that the triple mass balance consistently showed a predominantly two-source mix for the most likely scenarios (see Table 3 ).

For this test, each mass balance is formulated individually (Eqs. 4 and 5) and solved independently (in contrast to the triple mass balance which solves the three simultaneously):

$\delta^{13} \mathrm{C} \uparrow \mathrm{C} \cdot \Delta Q_{\mathrm{C}}=\delta^{13} \mathrm{C}_{1} \cdot \Delta Q_{1}+\delta^{13} \mathrm{C}_{2} \cdot \Delta Q_{2}$

$\delta \mathrm{D} \uparrow_{\mathrm{C}} \cdot \Delta Q_{\mathrm{C}}=\delta \mathrm{D}_{1} \cdot \Delta Q_{1}+\delta \mathrm{D}_{2} \cdot \Delta Q_{2}$

The sources included in the mass balances can be split into two groups. The first group $\left(\left\{\delta^{13} \mathrm{C}, \delta \mathrm{D}\right\}_{1} \cdot \Delta Q_{1}\right)$ includes the sources that are more ${ }^{13} \mathrm{C}$-enriched than the mean source $\delta^{13} \mathrm{CH}_{4} \uparrow \mathrm{T}$ value (biomass burning and GEM), and the second group $\left(\left\{\delta^{13} \mathrm{C}, \delta \mathrm{D}\right\}_{2} \cdot \Delta Q_{2}\right)$ includes sources more ${ }^{13} \mathrm{C}$ depleted (biogenic marine gas hydrates, tropical and boreal wetlands, thermokarst lakes, termites and APM) (see Fig. 7). The mass balances can then be calculated for each combination of a source from the ${ }^{13} \mathrm{C}$-enriched group and a source from the ${ }^{13} \mathrm{C}$-depleted group. The $\delta{ }^{13} \mathrm{C}_{\mathrm{C}}$ and $\delta \mathrm{D}_{\mathrm{C}}$ values are set to the $\delta^{13} \mathrm{CH}_{4} \uparrow_{\mathrm{T}}$ and $\delta \mathrm{D}-\mathrm{CH}_{4} \uparrow_{\mathrm{T}}$ values, respectively. $\Delta Q_{1}$ and $\Delta Q_{2}$ are the fractional contribution of each source, and $\Delta Q_{c}$ is set to unity.

Since these mass balances are for the same system, if they are accurately representing the actual source combination that forms the $\delta^{13} \mathrm{CH}_{4} \uparrow_{\mathrm{T}}$ and $\delta \mathrm{D}-\mathrm{CH}_{4} \uparrow \mathrm{T}$ values, the fractional contributions of the sources $\left(\Delta Q_{n}\right)$ for each mass balance, $\delta^{13} \mathrm{C}$ and $\delta \mathrm{D}$, should be equal, i.e. $\Delta Q_{1}$ from the $\delta^{13} \mathrm{C}$ mass balance should equal $\Delta Q_{1}$ from the $\delta \mathrm{D}$ mass balance. The larger the mismatch between the two mass balances' calculated source fractional contributions, the less likely those two sources accurately describe the source combination that formed the $\delta^{13} \mathrm{CH}_{4} \uparrow \mathrm{T}$ and $\delta \mathrm{D}-\mathrm{CH}_{4} \uparrow \mathrm{T}$ values. The results of all possible source combinations for the standard scenario are presented in Table 4 . We use the criteria of $\pm 10 \%$ of mismatch between the two mass balance source contributions to denote valid scenarios (similar to $1 \pm 0.1$ used in the triple mass balance). With these criteria, no twosource mixes using GEM as the ${ }^{13} \mathrm{C}$-enriched source are valid, with the closest being a $28 \%$ mismatch between the fractional source combinations calculated in the $\delta^{13} \mathrm{C}$ and $\delta \mathrm{D}$ mass balances. For mass balances with biomass burning as the ${ }^{13} \mathrm{C}$-enriched source, the valid scenarios suggest that the ${ }^{13} \mathrm{C}$-depleted component could be any of APM, boreal wetlands, thermokarst lakes, or termites. These valid scenarios predict a biomass burning fractional contribution between 0.28 and 0.48 . These values are less than those calculated by the triple mass balance; however, this test can only investigate two-component mixes, which will influence the fractional contribution values calculated. Exploring the uncertainty range around the $\delta^{13} \mathrm{CH}_{4} \uparrow_{\mathrm{T}}$ and $\delta \mathrm{D}-\mathrm{CH}_{4} \uparrow_{\mathrm{T}}$ values shows no valid scenarios with GEM as the ${ }^{13} \mathrm{C}$-enriched source, and no valid scenarios with either biogenic marine gas hydrates or tropical wetlands as the ${ }^{13} \mathrm{C}$-depleted source. When the $\delta^{13} \mathrm{CH}_{4} \uparrow_{\mathrm{T}}$ and $\delta \mathrm{D}-\mathrm{CH}_{4} \uparrow \mathrm{T}$ values are assumed to be $-50.4 \%$ and $-306 \%$, the combination of 
ruminants and biomass burning becomes a valid scenario. Of the source combinations that are valid scenarios for the mean $\delta^{13} \mathrm{CH}_{4} \uparrow \mathrm{T}$ and $\delta \mathrm{D}-\mathrm{CH}_{4} \uparrow \mathrm{T}$ values, none of them remain valid scenarios throughout the entire range of $\delta^{13} \mathrm{CH}_{4} \uparrow \mathrm{T}$ and $\delta \mathrm{D}-\mathrm{CH}_{4} \uparrow \mathrm{T}$ values tested (see Table 4 ).

These mass balance tests support the conclusion, from the triple mass balance, of a strong role for biomass burning at the YD-PB transition. The triple mass balance result of a strong role for thermokarst lakes remains plausible; however, these tests demonstrate that the unique role for thermokarst lakes is dependent upon the validity of the ${ }^{14} \mathrm{CH}_{4}$ dataset. If the use of, or data within, this dataset is not valid, then we are not able to distinguish the possible contribution of thermokarst lakes from that of APM, boreal wetlands or termites. This also adds uncertainty to the triple mass balance result of no strong role for boreal wetlands. Tropical wetlands and biogenic marine gas hydrates remain unlikely to have contributed greatly to the methane rise at the end of the YD.

\section{Conclusions}

We present a new $\delta^{13} \mathrm{CH}_{4}$ dataset measured from Påkitsoq ice covering the YD-PB transition. A ${ }^{13} \mathrm{C}$-enrichment trend across the transition is evident and well exceeds measurement uncertainty. The trend is also evident in previously published Påkitsoq measurements (Schaefer et al., 2006) using different experimental setups (Ferretti et al., 2005; Schaefer et al., 2006). While not unambiguous due to dating uncertainty, it appears that a similar disruption of the long-term deglaciation ${ }^{13} \mathrm{C}$-depletion trend occurred in the presently available Antarctica $\delta^{13} \mathrm{CH}_{4}$ record (Fischer et al., 2008).

A triple mass balance has been used to determine the most plausible source combination for the rapid $\left[\mathrm{CH}_{4}\right]$ increase during the YD-PB transition. The mass balance results show a strong role for biomass burning with an additional significant contribution from thermokarst lakes. The triple mass balance approach uses the best available $\delta^{13} \mathrm{CH}_{4}, \delta \mathrm{D}-\mathrm{CH}_{4}$, and ${ }^{14} \mathrm{CH}_{4}$ datasets, of which the ${ }^{14} \mathrm{CH}_{4}$ dataset (Petrenko et al. 2009) has high uncertainty and much lower temporal resolution. To determine the influence of our use of the ${ }^{14} \mathrm{CH}_{4}$ dataset, a separate mass balance approach using only $\delta^{13} \mathrm{CH}_{4}$ and $\delta \mathrm{D}-\mathrm{CH}_{4}$ was performed. This test supports a strong role for biomass burning, but could not distinguish the corresponding ${ }^{13} \mathrm{C}$-depleted source between aerobic plant methane, boreal wetlands, thermokarst lakes, and termites. These results then do not contradict the findings of the triple mass balance but do add extra uncertainty around the role of thermokarst lakes in the methane concentration rise. If the ${ }^{14} \mathrm{CH}_{4}$ dataset can be used, our conclusion of the dominance of biomass burning, and perhaps thermokarst lakes, seems qualitatively robust in spite of analytical uncertainties of the ice isotope records they are based on, as well as assumptions on past methane budgets as confirmed by sensitivity tests.
In contrast, the quantitative interpretation of the fluxes is subject to the uncertainties of analyses and assumptions. Our analysis agrees with an increase in thermokarst lake methane emissions as previously suggested (Walter et al., 2007; Petrenko et al., 2009) as both mass balance tests find a possible role for thermokarst lakes, but neither test finds a dominant role for tropical wetlands or biogenic marine gas hydrates. The suggestion of a strong role for biomass burning in the rapid methane mixing ratio increase during the YD-PB transition is novel. If our results can be confirmed, they would indicate that, as climate warms into the future as projected, special attention should be paid to the dynamics of biomass burning and thermokarst lakes. Both of these methane sources appear capable of responding to a changing climate with substantial increases in methane flux producing a positive feedback on the climate system.

\section{Supplementary material related to this article is available online at: http://www.clim-past.net/8/1177/ 2012/cp-8-1177-2012-supplement.pdf.}

Acknowledgements. This work was supported by Canadian Foundation for Climate and Atmospheric Sciences MAMMOTH Grant GR-417 (M. J. W.), NSERC Discovery Grant OGP010538998 (M. J. W.), NSERC-IPY Grant 350737-2007 (M. J. W.) and by the New Zealand Foundation for Research, Science and Technology contract C01X0703 (H. S.). Fieldwork was supported by NSF grants OPP0221470 (to J. Severinghaus) and OPP0221410 (to E. Brook), as well as American Chemical Society grant PRF 42551-AC2 (H. S.). We thank V. Petrenko, E. Brook, and J. Severinghaus for sharing their Påkitsoq gas records; P. Eby for lab assistance; and M. Arsenault, P. Rose, N. Ness for assistance in the field; and K. Lassey for his isotope disequilibrium model.

Edited by: H. Fischer

\section{References}

Allan, W., Lowe, D. C., and Cainey, J. M.: Active chlorine in the remote marine boundary layer: Modeling anomalous measurements of $\delta^{13} \mathrm{C}$ in methane, Geophys. Res. Lett., 28, 3239-3242, 2001.

Allan, W., Struthers, H., and Lowe, D. C.: Methane carbon isotope effects caused by atomic chlorine in the marine boundary layer: Global model results compared with Southern Hemisphere measurements, J. Geophys. Res., 112, D04306, doi:10.1029/2006jd007369, 2007.

Behrens, M., Schmitt, J., Richter, K. U., Bock, M., Richter, U. C., Levin, I., and Fischer, H.: A gas chromatography/combustion/isotope ratio mass spectrometry system for high-precision $\delta^{13} \mathrm{C}$ measurements of atmospheric methane extracted from ice core samples, Rapid Commun. Mass. Sp., 22, 3261-3269, doi:10.1002/Rcm.3720, 2008.

Bellisario, L. M., Bubier, J. L., Moore, T. R., and Chanton, J. P.: Controls on $\mathrm{CH}_{4}$ emissions from a northern peatland, Global Biogeochem. Сy., 13, 81-91, 1999. 
Bender, M., Malaizé, B., Orchardo, J., Sowers, T., and Jouzel, J.: High precision correlations of Greenland and Antarctica ice core records over the last $100 \mathrm{kyr}$ in: Global climate change at millenial timescales, edited by: Clark, P. U., Webb, R., and Keigwin, L., American Geophysical Union, Washington, D.C., 149-164, 1999.

Bock, M., Schmitt, J., Moller, L., Spahni, R., Blunier, T., and Fischer, H.: Hydrogen isotopes preclude marine hydrate $\mathrm{CH}_{4}$ emissions at the onset of Dansgaard-Oeschger events, Science, 328, 1686-1689, doi:10.1126/Science.1187651, 2010.

Bousquet, P., Ciais, P., Miller, J. B., Dlugokencky, E. J., Hauglustaine, D. A., Prigent, C., Van der Werf, G. R., Peylin, P., Brunke, E.-G., Carouge, C., Langenfelds, R. L., Lathiére, J., Papa, F., Ramonet, M., Schmidt, M., Steele, L. P., Tyler, S. C., and White, J. W. C.: Contribution of anthropogenic and natural sources to atmospheric methane variability, Nature, 443, 439-444, 2006.

Bowman, D. M. J. S., Balch, J. K., Artaxo, P., Bond, W. J., Carlson, J. M., Cochrane, M. A., D’Antonio, C. M., DeFries, R. S., Doyle, J. C., Harrison, S. P., Johnston, F. H., Keeley, J. E., Krawchuk, M. A., Kull, C. A., Marston, J. B., Moritz, M. A., Prentice, I. C., Roos, C. I., Scott, A. C., Swetnam, T. W., van der Werf, G. R., and Pyne, S. J.: Fire in the Earth system, Science, 324, 481-484, doi:10.1126/Science.1163886, 2009.

Brenninkmeijer, C. A. M., Lowe, D. C., Manning, M. R., Sparks, R. J., and vanVelthoven, P. F. J.: The ${ }^{13} \mathrm{C},{ }^{14} \mathrm{C}$ and ${ }^{18} \mathrm{O}$ isotopic composition of $\mathrm{CO}, \mathrm{CH}_{4}$, and $\mathrm{CO}_{2}$ in the higher southern latitudes lower stratosphere, J. Geophys. Res.-Atmos., 100, 2616326172, 1995.

Brook, E. J., Sowers, T., and Orchardo, J.: Rapid variations in atmospheric methane concentration during the past 110,000 years, Science, 273, 1087-1091, 1996.

Brook, E. J., Harder, S., Severinghaus, J., Steig, E. J., and Sucher, C. M.: On the origin and timing of rapid changes in atmospheric methane during the last glacial period, Global Biogeochem. Cy., 14, 559-572, 2000.

Brook, E. J., White, J. W. C., Schilla, A. S. M., Bender, M. L., Barnett, B., Severinghaus, J. P., Taylor, K. E., Alley, R. B., and Steig, E. J.: Timing of millennial-scale climate change at Siple Dome, West Antarctica, during the last glacial period, Quaternary Sci. Rev., 24, 1333-1343, 2005.

Buizert, C.: The influence of firn air transport processes and radiocarbon production on gas records from polar firn and ice, $\mathrm{PhD}$, Faculty of Science, University of Copenhagen, Denmark, Copenhagen, 175 pp., 2012.

Cantrell, C. A., Shetter, R. E., Mcdaniel, A. H., Calvert, J. G., Davidson, J. A., Lowe, D. C., Tyler, S. C., Cicerone, R. J., and Greenberg, J. P.: Carbon kinetic isotope effect in the oxidation of methane by the hydroxyl radical, J. Geophy. Res., 95, 2245522462, 1990.

Chappellaz, J., Barnola, J.-M., Raynaud, D., Korotkevich, Y. S., and Lorius, C.: Ice-core record of atmospheric methane over the past 160,000 years, Nature, 345, 127-131, 1990.

Chappellaz, J., Fung, I. Y., and Thompson, A. M.: The atmospheric $\mathrm{CH}_{4}$ increase since the Last Glacial Maximum (1) source estimates, Tellus B, 45, 228-241, 1993.

Collatz, G. J., Berry, J. A., and Clark, J. S.: Effects of climate and atmospheric $\mathrm{CO}_{2}$ partial pressure on the global distribution of C4 grasses: Present, past, and future, Oecologia, 114, 441-454, 1998.
Craig, H., Chou, C. C., Welhan, J. A., Stevens, C. M., and Engelkemeir, A.: The isotopic composition of methane in polar ice cores, Science, 242, 1535-1539, 1988.

Dällenbach, A., Blunier, T., Flückiger, J., Stauffer, B., Chappellaz, J., and Raynaud, D.: Changes in the atmospheric $\mathrm{CH}_{4}$ gradient between Greenland and Antarctica during the Last Glacial and the transition to the Holocene, Geophys. Res. Lett., 27, 10051008, 2000.

Daniau, A.-L., Harrison, S. P., and Bartlein, P. J.: Fire regimes during the Last Glacial, Quaternary Sci. Rev., 29, 2918-2930, doi:10.1016/j.quascirev.2009.11.008, 2010.

Denman, K. L., Brasseur, G. P., Chidthaisong, A., Ciais, P., Cox, P., Dickinson, R., Hauglustaine, D. A., Heinze, C., Holland, E., Jacob, D., Lohmann, U., Ramachandran, S., da Silva Dias, P. L., Wofsy, S. C., and Zhang, X.: Couplings between changes in the climate system and biogeochemistry, Cambridge University Press, Cambridge, UK and New York, NY, USA, 2007.

Donahue, D. J., Linick, T. W., and Jull, A. J. T.: Isotope-ratio and background correction for accelerator mass spectrometry radiocarbon measurements, Radiocarbon, 32, 135-142, 1990.

Drevet, J.: Modeling study of the interannual variability in global tropospheric hydroxyl radical and methane concentrations over the last two decades, PhD, Faculte Environnement Naturel, Architectural et Construit, École Polytechnique Fédérale de Lausanne, Switzerland, Lausanne, 133 pp., 2008.

EPICA Community Members: One-to-one coupling of glacial climate variability in Greenland and Antarctica, Nature, 444, 195198, doi:10.1038/Nature05301, 2006.

Etheridge, D. M., Steele, L. P., Francey, R. J., and Langenfelds, R. L.: Atmospheric methane between 1000 A.D. and present: Evidence of anthropogenic emissions and climatic variability, J. Geophys. Res., 103, 15979-15993, 1998.

Etiope, G., Milkov, A. V., and Derbyshire, E.: Did geologic emissions of methane play any role in Quaternary climate change?, Global Planet. Change, 61, 79-88, 2008.

Ferretti, D. F., Miller, J. B., White, J. W. C., Etheridge, D. M., Lassey, K. R., Lowe, D. C., MacFarling Meure, C. M., Dreier, M. F., Trudinger, C. M., van Ommen, T. D., and Langenfelds, R. L.: Unexpected changes to the global methane budget over the past 2000 years, Science, 309, 1714-1717, 2005.

Fischer, H., Behrens, M., Bock, M., Richter, U., Schmitt, J., Loulergue, L., Chappellaz, J., Spahni, R., Blunier, T., Leuenberger, M., and Stocker, T. F.: Changing boreal methane sources and constant biomass burning during the last termination, Nature, 452, 864-867, doi:10.1038/nature06825, 2008.

Friedrich, M., Kromer, B., Spurk, M., Hoffman, J., and Kaiser, K. F.: Paleo-environment and radiocarbon calibration as derived from Late Glacial/Early Holocene tree-ring chronologies, Quatern. Int., 61, 27-39, 1999.

Gierczak, T., Talukdar, R. K., Herndon, S. C., Vaghjiani, G. L., and Ravishankara, A. R.: Rate coefficients for the reactions of hydroxyl radicals with methane and deuterated methanes, J. Phys. Chem. A, 101, 3125-3134, 1997.

Grachev, A. M. and Severinghaus, J.: Determining the thermal diffusion factor for ${ }^{40} \mathrm{Ar} /{ }^{36} \mathrm{Ar}$ in air to aid paleoreconstruction of abrupt climate change, J. Phys. Chem. A, 107, 4636-4642, 2003.

Grootes, P. M. and Stuiver, M.: Oxygen 18/16 variability in Greenland snow and ice with $10^{3}$ to $10^{5}$ year time resolution, J. Geophys. Res., 102, 26455-26470, doi:10.1029/97jc00880, 1997. 
Herron, M. M. and Langway, C. C. J.: Firn densification: An empirical model, J. Glaciol., 25, 373-385, 1980.

Hill, T. M., Kennett, J. P., Valentine, D. L., Yang, Z., Reddy, C. M., Nelson, R. K., Behl, R. J., Robert, C., and Beaufort, L.: Climatically driven emissions of hydrocarbons from marine sediments during deglaciation, P. Natl. Acad. Sci., 103, 1357013574, 2006.

Irion, F. W., Moyer, E. J., Gunson, M. R., Rinsland, C. P., Yung, Y. L., Michelsen, H. A., Salawitch, R. J., Chang, A. Y., Newchurch, M. J., Abbas, M. M., Abrams, M. C., and Zanders, R.: Stratospheric observations of $\mathrm{CH} 3 \mathrm{D}$ and HDO from atmospheric infrared solar spectra: Enrichments of deuterium in methane and implications for HD, Geophys. Res. Lett., 23, 2381-2384, 1996.

Jones, M. C. and Yu, Z.: Rapid deglacial and early Holocene expansion of peatlands in Alaska, P. Natl. Acad. Sci., 107, 7347-7352, doi:10.1073/pnas.0911387107, 2010.

Jouzel, J., Hoffman, G., Koster, R. D., and Masson, V.: Water isotopes in precipitation: Data/model comparison for present-day and past climates, Quaternary Sci. Rev., 19, 363-379, 2000.

Kennett, J. P., Cannariato, K. G., Hendy, I. L., and Behl, R. J.: Methane hydrates in Quaternary climate change: The clathrate gun hypothesis, AGU Special Publication, 54, 216, 2003.

Keppler, F., Hamilton, J. T. G., Brab, M., and Röckmann, T.: Methane emissions from terrestrial plants under aerobic conditions, Nature, 439, 187-191, 2006.

King, S. L., Quay, P. D., and Lansdown, J. M.: The C-13/C-12 kinetic isotope effect for soil oxidation of methane at ambient atmospheric concentrations, J. Geophys. Res.-Atmos., 94, 18273$18277,1989$.

Korhola, A., Ruppel, M., Seppa, H., Valiranta, M., Virtanen, T., and Weckstrom, J.: The importance of northern peatland expansion to the late-Holocene rise of atmospheric methane, Quaternary Sci. Rev., 29, 611-617, doi:10.1016/J.Quascirev.2009.12.010, 2010.

Lassey, K. R., Lowe, D. C., and Manning, M. R.: The trend in atmospheric methane $\delta^{13} \mathrm{C}$ and implications for isotopic constraints on the global methane budget, Global Biogeochem. Cy., 14, 4149, 2000.

Lassey, K. R., Etheridge, D. M., Lowe, D. C., Smith, A. M., and Ferretti, D. F.: Centennial evolution of the atmospheric methane budget: what do the carbon isotopes tell us?, Atmos. Chem. Phys., 7, 2119-2139, doi:10.5194/acp-7-2119-2007, 2007.

Levine, J. G., Wolff, E. W., Jones, A. E., and Sime, L. C.: The role of atomic chlorine in glacial-interglacial changes in the carbon13 content of atmospheric methane, Geophys. Res. Lett., 38, L04801, doi:10.1029/2010GL046122, 2011.

MacDonald, G. M., Beilman, D. W., Kremenetski, K. V., Sheng, Y., Smith, L. C., and Velichko, A. A.: Rapid early development of circumarctic peatlands and atmospheric $\mathrm{CH}_{4}$ and $\mathrm{CO}_{2}$ variations, Science, 314, 285-289, 2006.

Marlon, J. R., Bartlein, P. J., Walsh, M. K., Harrison, S. P., Brown, K. J., Edwards, M. E., Higuera, P. E., Power, M. J., Anderson, R. S., Briles, C., Brunelle, A., Carcaillet, C., Daniels, M., Hu, F. S., Lavoie, M., Long, C., Minckley, T., Richard, P. J. H., Scott, A. C., Schafer, D. S., Tinner, W., Umbanhowar Jr., C. E., and Whitlock, C.: Wildfire responses to abrupt climate change in North America, P. Natl. Acad. Sci., 106, 2519-2524, doi:10.1073/pnas.0808212106, 2009.
Martinerie, P., Brasseur, G. P., and Granier, C.: The chemical composition of ancient atmospheres: A model study constrained by ice core data, J. Geophys. Res., 100, 14291-14304, 1995.

Melton, J. R.: Methane stable isotope dynamics spanning the last deglaciation, $\mathrm{PhD}$, School of Earth and Ocean Sciences, University of Victoria, Canada, Victoria, 188 pp., 2010.

Melton, J. R., Whiticar, M. J., and Eby, P.: Stable carbon isotope ratio analyses on trace methane from ice samples, Chem. Geol., 288, 88-96, doi:10.1016/j.chemgeo.2011.03.003, 2011.

Mischler, J. A., Sowers, T. A., Alley, R. B., Battle, M., McConnell, J. R., Mitchell, L., Popp, T., Sofen, E., and Spencer, M. K.: Carbon and hydrogen isotopic composition of methane over the last 1000 years, Global Biogeochem. Cy., 23, GB4024, doi:10.1029/2009GB003460, 2009.

Möller, L., Sowers, T., Bock, M., Spahni, R., Behrens, M., Schmitt, J., Miller, H., and Fischer, H.: Climate and $\mathrm{CO}_{2}$ control on emissions and ecosystem composition of global methane sources over the last 160,000 years derived from $\delta^{13} \mathrm{CH}_{4}$ in ice cores, Geophys. Res. Abstr. Vol. 14, EGU2012-2366,http://meetingorganizer.copernicus.org/ EGU2012/EGU2012-13164.pdf (last access: July 2012), 2012.

Nakagawa, F., Yoshida, N., Nojiri, Y., and Makarov, V. N.: Production of methane from alasses in Eastern Siberia: Implications from its ${ }^{14} \mathrm{C}$ and stable isotope compositions, Global Biogeochem. Cy., 16, 1041-1056, 2002a.

Nakagawa, F., Yoshida, N., Sugimoto, A., Wada, E., Yoshioka, T., Ueda, S., and Vijarnsorn, P.: Stable isotope and radiocarbon compositions of methane emitted from tropical rice paddies and swamps in Southern Thailand, Biogeochemistry, 61, 1-19, 2002b.

Nisbet, R. E. R., Fisher, R., Nimmo, R. H., Bendall, D. S., Crill, P. M., Gallego-Sala, A. V., Hornibrook, E. R. C., LópezJuez, E., Lowry, D., Nisbet, P. B. R., Shuckburgh, E. F., Sriskantharajah, S., Howe, C. J., and Nisbet, E. G.: Emissions of methane from plants, P. Roy. Soc. B, 276, 1459-1468, doi:10.1098/rspb.2008.1731, 2009.

Peterson, L. C., Haug, G. H., Hughen, K. A., and Rohl, U.: Rapid changes in the hydrologic cycle of the tropical atlantic during the Last Glacial, Science, 290, 1947-1951, 2000.

Petrenko, V., Severinghaus, J., Brook, E. J., Reeh, N., and Schaefer, H.: Gas records from the West Greenland ice margin covering the last glacial maximum termination: A horizontal ice core, Quaternary Sci. Rev., 25, 865-875, 2006.

Petrenko, V., Smith, A. M., Brook, E. J., Lowe, D. C., Riedel, K., Brailsford, G. W., Hua, Q., Schaefer, H., Reeh, N., Weiss, R. F., Etheridge, D. M., and Severinghaus, J.: ${ }^{14} \mathrm{CH}_{4}$ measurements in Greenland ice: Investigating Last Glacial termination $\mathrm{CH}_{4}$ sources, Science, 324, 506-508, 2009.

Power, M. J., Marlon, J. R., Ortiz, N., Bartlein, P. J., Harrison, S. P., Mayle, F. E., Ballouche, A., Bradshaw, R. H. W., Carcaillet, C., Cordova, C., Mooney, S., Moreno, P. I., Prentice, C. I., Thonicke, K., Tinner, W., Whitlock, C., Zhang, Y., Zhao, Y., Ali, A. A., Anderson, R. S., Beer, R., Behling, H., Briles, C., Brown, K. J., Brunelle, A., Bush, M., Camil, P., Chu, G. Q., Clark, J., Colombarli, D., Connor, S., Daniau, A.-L., Daniels, M., Dodson, J., Doughty, E., Edwards, M. E., Finsinger, W., Foster, D., Frechette, J., Gaillard, M.-J., Gavin, D. G., Gobet, E., Haberle, S., Hallett, D. J., Higuera, P. E., Hope, G., Horn, S., Inoue, J., Kaltenrieder, P., Kennedy, L., Kong, Z. C., Larsen, C., Long, C. 
J., Lynch, J., Lynch, E. A., McGlone, M., Meeks, S., Mensing, S., Meyer, G., Minckley, T., Mohr, J., Nelson, D. M., New, J., Newnham, R., Noti, R., Oswald, W., Pierce, J., Richard, P. J. H., Rowe, C., Sanchez Goñi, M. F., Shuman, B. N., Takahara, H., Toney, J., Turney, C., Urrego-Sanchez, D. H., Umbanhowar Jr., C. E., Vandergoes, M., Vanniere, B., Vescovi, E., Walsh, M. K., Wang, X., Williams, N., Wilmshurst, J., and Zhang, J. H.: Changes in fire regimes since the Last Glacial Maximum: An assessment based on a global synthesis and analysis of charcoal data, Clim. Dynam., 30, 887-907, doi:10.1007/s00382-007-0334-x, 2008.

Quay, P., Stutsman, J., Wilbur, D., Snover, A., Dlugokencky, E. J., and Brown, T.: The isotopic composition of atmospheric methane, Global Biogeochem. Cy., 13, 445-461, 1999.

Reeburgh, W. S., Hirsch, A. I., Sansone, F. J., Popp, B. N., and Rust, T. M.: Carbon kinetic isotope effect accompanying microbial oxidation of methane in boreal forest soils, Geochim. Cosmochim. Acta, 61, 4761-4767, 1997.

Reyes, A. V. and Cooke, C. A.: Northern peatland initiation lagged abrupt increases in deglacial atmospheric $\mathrm{CH}_{4}$, P. Natl. Acad. Sci., 108, 4748-4753, doi:10.1073/pnas.1013270108, 2011.

Saueressig, G., Bergamaschi, P., Crowley, J. N., Fischer, H., and Harris, G. W.: Carbon kinetic isotope effect in the reaction of $\mathrm{CH}_{4}$ with $\mathrm{Cl}$ atoms, Geophys. Res. Lett., 22, 1225-1228, 1995.

Saueressig, G., Crowley, J. N., Bergamaschi, P., Bruhl, C., Brenninkmeijer, C. A. M., and Fischer, H.: Carbon 13 and D kinetic isotope effects in the reactions of $\mathrm{CH} 4$ with $\mathrm{O}(\mathrm{D}-1)$ and $\mathrm{OH}$ : New laboratory measurements and their implications for the isotopic composition of stratospheric methane, J. Geophys. Res.-Atmos., 106, 23127-23138, 2001.

Schaefer, H.: Stable carbon isotopic composition of methane from ice samples, PhD, School of Earth and Ocean Sciences, University of Victoria, Victoria, 166 pp., 2005.

Schaefer, H. and Whiticar, M. J.: Measurement of stable carbon isotope ratio of methane in ice samples, Org. Geochem., 38, 216226, 2007.

Schaefer, H. and Whiticar, M. J.: Potential glacial-interglacial changes in stable carbon isotope ratios of methane sources and sink fractionation, Global Biogeochem. Cy., 22, GB1001, doi:10.1029/2006GB002889, 2008.

Schaefer, H., Whiticar, M. J., Brook, E. J., Petrenko, V., Ferretti, D. F., and Severinghaus, J.: Ice record of $\delta^{13} \mathrm{C}$ for atmospheric $\mathrm{CH}_{4}$ across the Younger Dryas-Preboreal transition, Science, 313, 1109-1112, 2006.

Schaefer, H., Petrenko, V., Brook, E. J., Severinghaus, J., Reeh, N., Melton, J. R., and Mitchell, L.: Ice stratigraphy at the Pakitsoq West Greenland ice margin derived from gas records, J. Glaciol., 55, 411-422, 2009.

Schrag, D. P., Adkins, J. F., McIntyre, K., Alexander, J. L., Hodell, D. A., Charles, C. D., and McManus, J. F.: The oxygen isotopic composition of seawater during the Last Glacial Maximum, Quaternary Sci. Rev., 21, 331-342, 2002.

Schwander, J., Barnola, J.-M., Andrié, C., Leuenberger, M., Ludin, A., Raynaud, D., and Stauffer, B.: The age of the air in the firn and the ice at Summit, Greenland, J. Geophys. Res., 98, 28312838, 1993.

Schwander, J., Sowers, T., Barnola, J.-M., Blunier, T., Fuchs, A., and Malaizé, B.: Age scale of the air in the Summit ice: Implications for glacial-interglacial temperature change, J. Geophys. Res., 102, 19483-419493, 1997.
Severinghaus, J., Sowers, T., Brook, E. J., Alley, R. B., and Bender, M.: Timing of abrupt climate change at the end of the Younger Dryas interval from thermally fractionated gases in polar ice, Nature, 391, 141-146, 1998.

Severinghaus, J., Beaudette, R., Headly, M. A., Taylor, K. C., and Brook, E. J.: Oxygen-18 of $\mathrm{O}_{2}$ records the impact of abrupt climate change on the terrestrial biosphere, Science, 324, 14311434, doi:10.1126/science.1169473, 2009.

Snover, A. K. and Quay, P. D.: Hydrogen and carbon kinetic isotope effects during soil uptake of atmospheric methane, Global Biogeochem. Cy., 14, 25-39, 2000.

Sowers, T.: Late quaternary atmospheric $\mathrm{CH}_{4}$ isotope record suggests marine clathrates are stable, Science, 311, 838-840, 2006.

Sowers, T.: Atmospheric methane isotope records covering the Holocene period, Quaternary Sci. Rev., 29, 213-221, doi:10.1016/j.quascirev.2009.05.023, 2010.

Stevens, G. A. and de Vries, A. E.: The influence of the distribution of atomic masses within the molecule on thermal diffusion, II. Isotopic methane and methane/argon mixtures, Physica, 39, 346-360, 1968.

Tans, P. P.: A note on isotopic ratios and the global atmospheric methane budget, Global Biogeochem. Cy., 11, 77-81, 1997.

Thompson, A. M., Chappellaz, J., Fung, I. Y., and Kucsera, T. L.: The atmospheric $\mathrm{CH}_{4}$ increase since the Last Glacial Maximum, Tellus B, 45, 242-257, 1993.

Trudinger, C. M., Enting, I. G., Etheridge, D. M., Francey, R. J., Levchenko, V. A., Steele, L. P., Raynaud, D., and Arnaud, L.: Modeling air movement and bubble trapping in firn, J. Geophys. Res., 102, 6747-6763, 1997.

Tyler, S. C., Crill, P. M., and Brailsford, G. W.: ${ }^{13} \mathrm{C} /{ }^{12} \mathrm{C}$ fractionation of methane during oxidation in a temperate forested soil, Geochim. Cosmochim. Acta, 58, 1625-1633, 1994.

Tyler, S. C., Ajie, H. O., Rice, A. L., Cicerone, R. J., and Tuazon, E. C.: Experimentally determined kinetic isotope effects in the reaction of $\mathrm{CH}_{4}$ with $\mathrm{Cl}$ : Implications for atmospheric $\mathrm{CH}_{4}$, Geophys. Res. Lett., 27, 1715-1718, 2000.

Vigano, I., Röckmann, T., Holzinger, R., van Dijk, A., Keppler, F., Greule, M., Brand, W. A., Geilmann, H., and van Weelden, H.: The stable isotope signature of methane emitted from plant material under UV radiation, Atmos. Environ., 43, 5637-5646, doi:10.1016/j.atmosenv.2009.07.046, 2009.

Wahlen, M., Deck, B., Shemesh, A., Fairbanks, R. G., Broecker, W. S., Weyer, H., Marino, B., and Logan, J.: Profiles of $\delta^{13} \mathrm{C}$ and $\delta \mathrm{D}$ of $\mathrm{CH}_{4}$ from the lower stratosphere, EOS Transactions AGU, 70, p. 1017, 1989a.

Wahlen, M., Tanaka, N., Henry, R., Deck, B., Zeglen, J., Vogel, J. S., Southon, J., Shemesh, A., Fairbanks, R. G., and Broecker, W. S.: Carbon-14 in methane sources and in atmospheric methane: The contribution from fossil carbon, Science, 245, 286-290, 1989b.

Waldron, S., Lansdown, J. M., Scott, E. M., Fallick, A. E., and Hall, A. J.: The global influence of the hydrogen isotope composition of water on that of bacteriogenic methane from shallow freshwater environments, Geochim. Cosmochim. Acta, 63, 2237-2245, 1999.

Walter, K. M., Zimov, S. A., Chanton, J. P., Verbyla, D., and Chapin, F. S. I.: Methane bubbling from Siberian thaw lakes as a positive feedback to climate warming, Nature, 443, 71-76, doi:10.1038/nature05040, 2006. 
Walter, K. M., Edwards, M. E., Grosse, G., Zimov, S. A., and Chapin, F. S. I.: Thermokarst lakes as a source of atmospheric $\mathrm{CH}_{4}$ during the Last Deglaciation, Science, 318, 633638, 10.1126/science.1142924, 2007.

Walter, K. M., Chanton, J. P., Chapin, F. S., Schuur, E. A. G., and Zimov, S. A.: Methane production and bubble emissions from arctic lakes: Isotopic implications for source pathways and ages, J. Geophys. Res.-Biogeo., 113, G00A08, doi:10.1029/2007jg000569, 2008.

Wang, Z., Chappellaz, J., Park, K., and Mak, J. E.: Large variations in Southern Hemisphere biomass burning during the last 650 years, Science, 330, 1663-1666, 2010.

Westerling, A. L., Hidalgo, H. G., Cayan, D. R., and Swetnam, T. W.: Warming and earlier spring increase Western U.S. forest wildfire activity, Science, 313, 940-943, doi:10.1126/science.1128834, 2006.

Westerling, A. L.: Wildfires, in: Climate change science and policy, edited by: Schneider, S. H., Rosencranz, A., Mastrandrea, M. D., and Kuntz-Duriseti, K., Island Press, Washington, D.C., USA, 92-104, 2009.
Whiticar, M. J.: Stable isotopes and global budgets, in: Atmospheric methane: Sources, sinks, and role in global climate, edited by: Khalil, M. A. K., Springer-Verlag, Berlin, Heidelberg, 138-167, 1993.

Whiticar, M. J.: Carbon and hydrogen isotope systematics of bacterial formation and oxidation of methane, Chem. Geol., 161, 291314, 1999.

Whiticar, M. J. and Schaefer, H.: Constraining past global tropospheric methane budgets with carbon and hydrogen isotope ratios in ice, P. Roy. Soc., 365, 1793-1828, doi:10.1098/rsta.2007.2048, 2007.

Winckler, G., Aeschbach-Hertig, W., Holocher, J., Kipfer, R., Levin, I., Poss, C., Rehder, G., Suess, E., and Schlosser, P.: Noble gases and radiocarbon in natural gas hydrates, Geophys. Res. Lett., 29, 63-1-63-4, doi:10.1029/2001gl014013, 2002.

Wuebbles, D. J. and Hayhoe, K.: Atmospheric methane and global change, Earth-Sci. Rev., 57, 177-210, 2002.

Zimov, S. A., Schuur, E. A. G., and Chapin, F. S. I.: Permafrost and the global carbon budget, Science, 312, 1612-1613, 2006. 